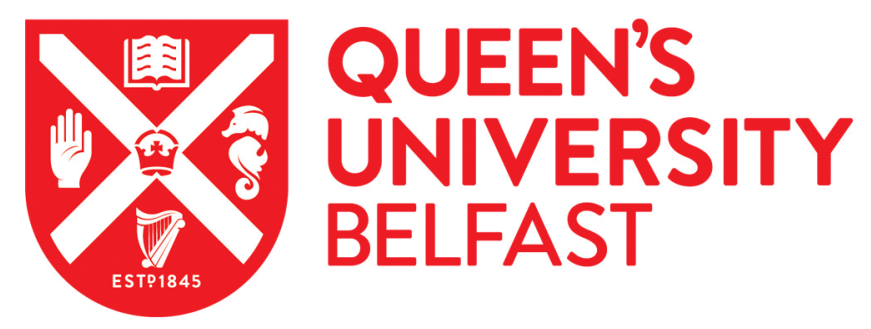

\title{
Empirical model for Darrieus-type tidal current turbine induced seabed scour
}

Sun, C., Lam, W. H., Cui, Y., Zhang, T., Jang, J., Guo, J., Ma, Y., Wang, S., Tan, T. H., Chuah, J. H., Lam, S. S., \& Hamill, G. (2018). Empirical model for Darrieus-type tidal current turbine induced seabed scour. Energy Conversion and Management, 171, 478-490. https://doi.org/10.1016/j.enconman.2018.06.010

Published in:

Energy Conversion and Management

Document Version:

Peer reviewed version

Queen's University Belfast - Research Portal:

Link to publication record in Queen's University Belfast Research Portal

Publisher rights

Copyright 2018 Elsevier Ltd.

This manuscript is distributed under a Creative Commons Attribution-NonCommercial-NoDerivs License

(https://creativecommons.org/licenses/by-nc-nd/4.0/), which permits distribution and reproduction for non-commercial purposes, provided the author and source are cited.

\section{General rights}

Copyright for the publications made accessible via the Queen's University Belfast Research Portal is retained by the author(s) and / or other copyright owners and it is a condition of accessing these publications that users recognise and abide by the legal requirements associated with these rights.

Take down policy

The Research Portal is Queen's institutional repository that provides access to Queen's research output. Every effort has been made to ensure that content in the Research Portal does not infringe any person's rights, or applicable UK laws. If you discover content in the Research Portal that you believe breaches copyright or violates any law, please contact openaccess@qub.ac.uk. 


\title{
Empirical model for Darrieus-type tidal current turbine induced seabed scour
}

Chong Sun ${ }^{12}$, Wei-Haur Lam ${ }^{12 *}$, Yonggang Cui ${ }^{12}$, Tianming Zhang ${ }^{12}$, Jinxin Jiang ${ }^{12}$, Jianhua Guo ${ }^{12}$, Yanbo $\mathrm{Ma}^{12}$, Shuguang Wang ${ }^{12}$, Gerard Hamill ${ }^{3}$; SuShiung Lam $^{4}$

${ }^{1}$ State Key Laboratory of Hydraulic Engineering Simulation and Safety, Tianjin University, People's Republic of China

${ }^{2}$ First R\&D Services, A-08-16 M Suites, 283 Jalan Ampang, 50450 Kuala Lumpur, Malaysia.

${ }^{3}$ School of Natural and Built Environment, Architecture, Civil \& Structural

Engineering and Planning, Queen's University Belfast, David Keir Building, Stranmillis Road, Belfast, BT9 5AG, United Kingdom.

${ }^{4}$ Pyrolysis Technology Research Group, Eastern Corridor Renewable Energy Group (ECRE), School of Ocean Engineering, Universiti Malaysia Terengganu, 21030 Kuala Nerus, Terengganu, Malaysia.

Corresponding email: wlam@tju.edu.cn; joshuawhlam@hotmail.com

\begin{abstract}
:
Tidal current turbine has attracted more attentions, but the impact of Darrieus-type tidal current turbine on the seabed scour process still remains unclear. This work aims to propose an empirical model, which can be used to predict the seabed scour depth against different tip clearance and rotor radius. The study also presents the scour profiles along centreline of turbine by using the proposed empirical equations. A series of 3D-printed turbine models was placed in a circulating water flume to investigate the scour profiles. The results suggest that the scour depth increases with the decrease of tip clearance. When the turbine is installed so close to seabed, the scour process is live bed scour with the collapse of the slant bed and scour depth does not further increase with the continuous decrease of tip clearance. The current experimental results proposed that the maximum scour depth is about $80 \%$ deeper than single pile induced seabed scour. Scour depth increases firstly and then decrease with the increase of rotor radius. Based on experimental results, an empirical model of Darrieus-type tidal current turbine induced seabed scour is proposed to predict the maximum scour depth and scour profiles.
\end{abstract}

Keywords: Darrieus-type tidal current turbine, seabed scour, renewable energy, empirical model 


\section{Introduction}

The development of marine renewable energy has huge potential to reduce environmental pollution and ease energy shortages [1]. As a clean and pollution-free renewable energy, tidal current energy has advantages of rich resource reveres, wide distribution and high predictability compared to other energy sources [2]. Interest in the use of tidal current energy has been growing over the past years.

Tidal current turbines can be categorized as either vertical-axis, or horizontal-axis turbines with different relative orientation between flow and rotation axis [3]. The development of Darrieus-type tidal current turbine has gained more and more interest due to its ability to capture the energy from various directions without adjusting the turbine position. The original concept of the Darrieus-type turbine was patented by French engineer George Darrieus in 1931 [4]. Since that time many applications and improvements have been devised to extract tidal current energy.

The impact of tidal current turbine to seabed is an essential issue when carries on the engineering design and installation of tidal current turbine. For Darrieus-type tidal current turbine with monopile foundation, the formation of horse vortex can happen in front of the monopile structure, whereas the formation of wake vortices can happen behind the monopile structure [5]. The turbine rotor changes the boundary layer profile, and consequently alters the formation of horseshoe vortex. The action of flow contraction accelerates the flow between turbine and seabed. Hence the scour depth increases compared to scour at piles.

Seabed scour around a pier or pile has been widely studied in the past years. The characters of fluid, bed material, flow, and geometry of offshore foundation may influent the scour phenomenon. In 1973, Neill [6] proposed a simple equation supposing that scour depth divided by diameter of the structure is a constant $\left(K_{S}\right)$, where $K_{S}$ is the correction factor of pier shape. Breusers et al. [7] improved an empirical equation to predict the scour depth with consideration of bed conditions, size of bed sediment, current velocity, and water depth based on series of experiments in 1977. Richardson and Davis [8] adopted Froude number in their expression. Sumer et al. [9] carried out the experimental investigation on scour around piles exposed to waves. Recently, Simons et al. [10] indicated that seabed scour is reduced in two-direction flow compared to unidirectional flow. Whitehouse [11] proposed a scour time evolution predictor (STEP) to predict the development of scour evolution of offshore structures. These researches can be foundation to study the Darrieus-type tidal current turbine induced seabed scour.

The existence of turbine rotor makes the seabed scour phenomenon more complex. The investigation of flow field around tidal current turbine is an initial input to study Darrieus-type tidal current turbine induced seabed scour. For horizontal-axis tidal current turbine, Sun et al. [12] used the actuator disk model to estimate the near wake 
of horizontal-axis tidal current turbine. Harrison et al. [13] conducted CFD (computational fluid dynamics) simulation to research the wake behaviour of tidal current turbine, and compared to the experimental results. Lam and Chen [14] proposed two equations to predict the wake characteristics based on the fundamental works of ship propeller jet. Tahani et al. [15] used the multi objective optimization of the horizontal-axis tidal current turbine to achieve its optimum performance. Lam and Chen [16] also used CFD simulation to investigate the slipstream between marine current turbine and seabed. Their results indicated the flow acceleration phenomenon occurred below the tidal current turbine. For Darrieus-type turbine, Ghasemian et al. [17] review the computational fluid dynamic simulation techniques for Darrieus-type wind turbines. Wang et al. [18] proposed a potential flow 2D vortex panel model to calculate unsteady hydrodynamics of Darrieus-type tidal current turbine for tidal streams energy conversion. Dai and Lam [19] used CFD simulation to predict the rotor performance and hydrodynamic loads of Darrieus-type tidal current turbine for structural design calculations. In addition, the double multiple streamtube (DMS) model, which was originally developed by Strickland [20] based on the momentum models, can also be used to investigate the hydrodynamic performance of turbine. However, there is few researches focus on the flow field around Darrieus-type tidal current turbine.

To date, the researches of scour characteristics around tidal current turbine are still limited. Chen and Lam [21] reviewed the numerical equations to predict the seabed scour around piles. C Hill et al. [22] performed laboratory experiments to study the effect of an axial-flow hydrokinetic turbine model on an erodible channel. The results indicated that the presence of turbine rotor increased the local shear stress and accelerated the scour development. Jisheng Zhang [23] developed a mathematical model to numerically investigate the fluid-structure interaction and its induced sediment scour around a horizontal-axis tidal current turbine. Giles et al. [24] presented a preliminary experimental study investigating the potential benefits of foundationbased flow acceleration structures for tidal current turbine and its function of scour protection. However, all above researches were focused on horizontal-axis tidal current turbine, the scour profiles of Darrieus-type tidal current turbine induced seabed scour is still unavailable.

In the current research, experimental work has been performed in Marine Renewable Energy Laboratory at Tianjin University. Vertical and horizontal extents of scour hole are studied at various tip clearance and radius of turbines. After series of experimental tests, an empirical model for Darrieus-type tidal current turbine induced seabed scour was proposed. The outcomes of the study provide a fundamental understanding on the scour nature of Darrieus-type tidal current turbine. 


\section{Comparison of three types of seabed scour}

Seabed scour around tidal current turbine has been well recognized as an engineering issue for its possibility to cause structural instability. A lot of researches have been done on the scour prediction of two forms: scour induced by propeller wash and scour near piers or piles. These researches can be references for Darrieus-type tidal current turbine induced scour. The comparison of these three types of seabed scour is listed in table 1.

Table 1. Comparison of three types of scour process

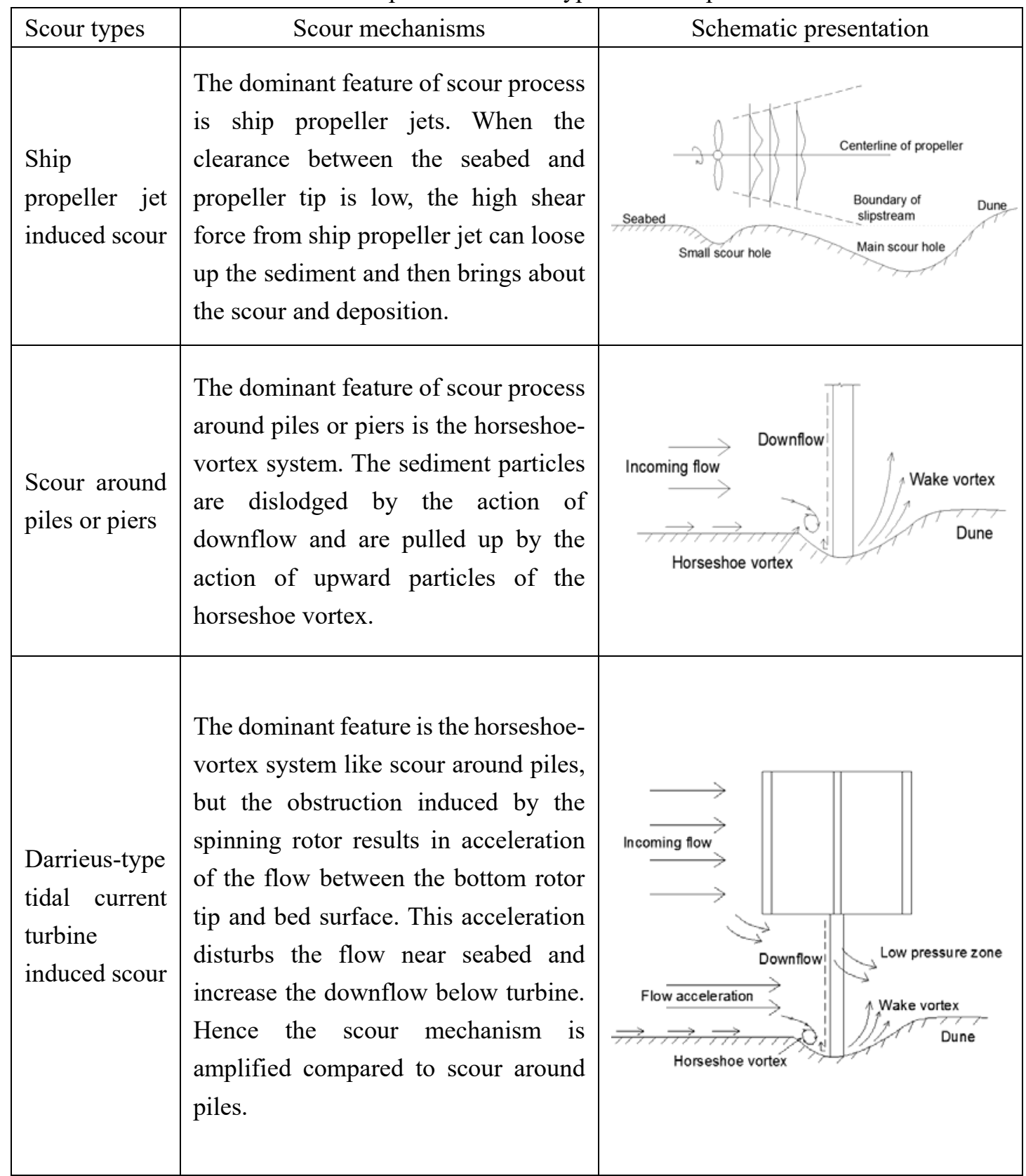

The process of Darrieus-type tidal current turbine induced seabed scour is like scour around a pile, but the evidence of rotor makes the scour hole deeper. The dominant feature of scour process around the foundation of turbine is the horse-vortex system. 
The sediment profile is dislodged by the action of downflow and subsequently pulled up by the upward velocity of the horseshoe velocity. The equilibrium of scour depth can achieve when the magnitude of vertically downwards flow can no longer move surface sediment of scour hole [7]. The turbine rotor blocks the flow and accelerates current velocity between turbine and seabed. Hence the equilibrium of sour process can be disturbed, and magnitude of scour depth is relatively increased.

To date, there are many researches focus on the scour issues around piles or piers, and numerous equations have been proposed to estimate the scour depth [6-11]. In addition, the researches of ship propeller jet induced scour can also be the references for turbine induced scour since that many similarities in hydrodynamics characteristics can be found between ship propeller and tidal current turbine. Seabed scour due to ship propeller jet has also been highlighted by many researchers [25-27]. However, little knowledge can be found on the tidal current turbine induced seabed scour. The scour depth around Darrieus-type tidal current turbine will be under-predicted applying numerical model of scour around piles. In the current study, an empirical model for Darrieus-type tidal current turbine induced seabed scour is proposed to predict the scour depth and spatial scour profile, which will be presented in section 5.

\section{Experiment Setup}

Scour experiments were carried out in Marine Renewable Energy Laboratory at Tianjin University. The tests were performed in a circulating water flume where the flow was driven by a propeller. The overall flume was $1.8 \mathrm{~m}$ long, $0.8 \mathrm{~m}$ wide and $0.6 \mathrm{~m}$ deep, and each circulating channel was $0.35 \mathrm{~m}$ wide. The water depth was kept in $0.3 \mathrm{~m}$ during the experiments. The flume was built with Plexiglas to make it visible from outside. An aluminium frame was set up to install measuring equipment. The velocity of the incoming flow was monitored by a pitot tube, and scour depth was measured by the laser rangefinder.

The Darrieus-type tidal current turbine models were installed in the centre of channel. The turbine support tower and rotor were manufactured by Three-dimensional printer using plastic materials. The 3D printing technology has advantage of rapid modelling and high precision, which is applicable to manufacture complex models. The turbine models used in the experiments were three blade Darrieus-type tidal current turbine with different rotor radius from $37.4 \mathrm{~mm}$ to $56.3 \mathrm{~mm}$. The turbine was outfitted with a miniature DC motor to achieve the rotational speed of $110 \mathrm{rpm}$. The rotational speed was measured by non-contact detecting device of rotation rate. The diameter of the turbine tower was $0.01 \mathrm{~m}$. The sediment was packed with a plastic box which was nearly $0.6 \mathrm{~m}$ length and $0.1 \mathrm{~m}$ tall. The experiments section consisted of nearly uniform sediment material $\left(d_{50}=1.1 \mathrm{~mm}\right)$, which was first levelled using a sand leveller. Turbine tower was adhered to the bottom of the box below the sediment surface. The box had two inclined planes at both the beginning and the end of the test section to ensure a smooth flow and prevent the box from disturbing the scour process. Fig. 1 shows a 
photo of the test section, turbine, and instrumentation used during experiments. A series of tests were investigated: 3 cases of different radius and 4 cases of different tip clearance.

During the experiments, the flume was slowly filled with water and flow was driven gradually by propeller in order to prevent the disturbance of the sand bed. The test section was $0.3 \mathrm{~m}$ upstream and $0.3 \mathrm{~m}$ downstream from the turbine tower, preventing the effects of inlet and outlet boundary conditions on scour process. The incoming velocity $0.23 \mathrm{~m} / \mathrm{s}$ were maintained constantly during the experiment. The incoming flow velocity was below the threshold velocity of movement of the bed material. A flowequalizing equipment was installed in front of the test section to make the flow field more homogeneous. The detailed parameters of each test were shown in table 2. It was noteworthy that the circulating water flume was not large, hence the flow velocity near outer wall was a little quicker than the flow velocity near inner wall. The approaching velocity was expressed as the standard velocity of different width positions at same axial location. During the experiment, the laser distance meter measured the bed elevation for each $0.5 \mathrm{~cm}$ in length and $0.5 \mathrm{~cm}$ in width. The temporal and spatial results of scour process is presented and discussed in section 4 .
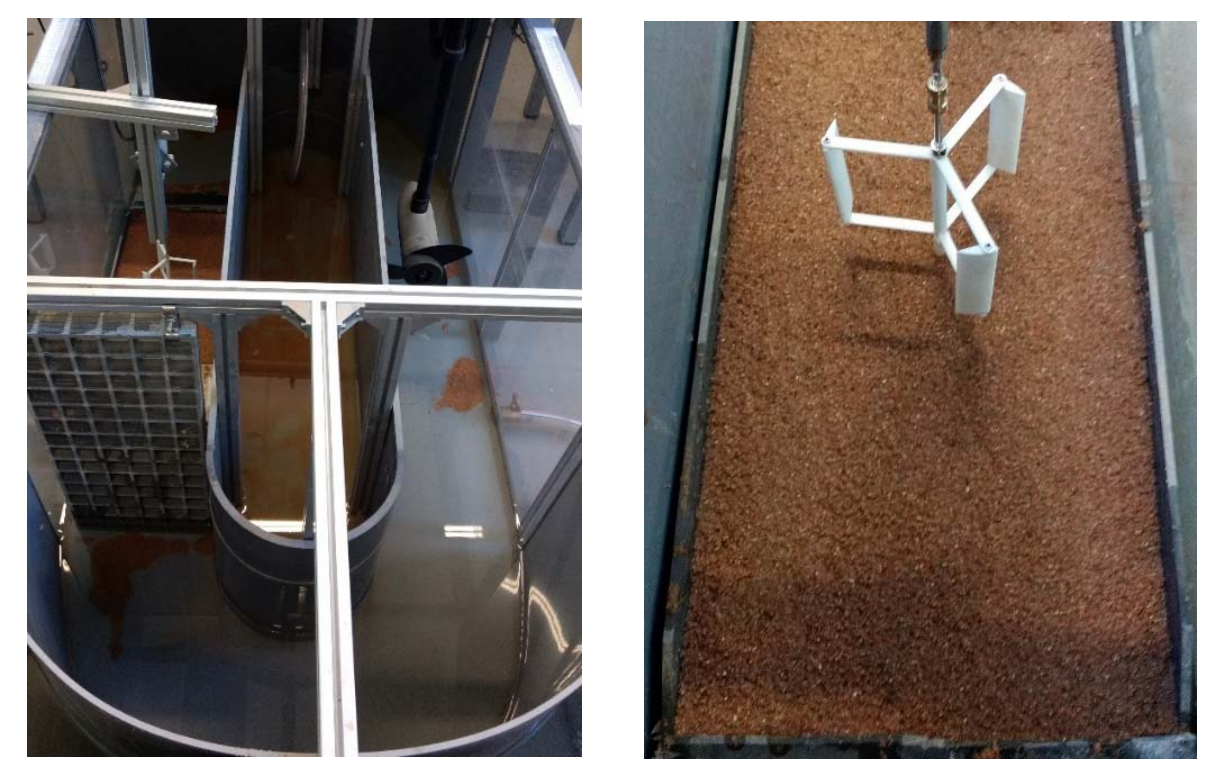

Figure 1: Experimental setup of model and instrumentation 
Table 2: Turbine, flow flume and sediment parameter used during the experiment

\begin{tabular}{llll}
\hline Variable & \multicolumn{1}{l}{ Clear water } & Variable & Clear water \\
\hline \multicolumn{2}{l}{ Turbine parameters } & Flow, channel, sediment parameters \\
\hline$R(\mathrm{~mm})$ & $56.3,45.9,37.4$ & $h(\mathrm{~m})$ & 0.3 \\
$H(\mathrm{~mm})$ & 87.5 & $Q_{w}\left(\mathrm{~m}^{3} / \mathrm{s}\right)$ & 0.024 \\
$c(\mathrm{~mm})$ & 20.4, & $b(\mathrm{~m})$ & 0.35 \\
Hydrofoil & NACA0025 & $F_{r}$ & 0.13 \\
$C / H$ & $0.25,0.5,0.75,1$ & $d_{50}(\mathrm{~mm})$ & 1.1 \\
$D(\mathrm{~mm})$ & 10 & $U_{c}(\mathrm{~m} / \mathrm{s})$ & 0.23 \\
$\omega(\mathrm{rpm})$ & 110 & $U_{c r}(\mathrm{~m} / \mathrm{s})$ & 0.25 \\
\hline
\end{tabular}

\section{Experimental Results and Discussion}

Experimental results will be presented in this section. The spatial scour profiles after reaching the equilibrium will be displayed first, followed by the result of scour profiles along the centreline of supporting pile at streamwise direction. Then the maximum scour depth at various tip clearance and rotor radius will be presented.

\subsection{Spatial scour profile}

The 3D surface maps after reaching scour equilibrium at various tip clearance between the seabed and turbine $(\mathrm{C} / \mathrm{H}=1,0.75,0.5,0.25$, respectively) are shown in Fig. 2(a-d). In each case, the tip clearance has been normalized by the rotor height. The final bed topography has subtracted initial flat surface and normalized by the diameter of supporting pile. In Fig.2 (a-d), the original point is centre of supporting pile. The $\mathrm{x}$-axis shows the streamwise direction, ranging from 4.5D upstream and $8.5 \mathrm{D}$ downstream. During the current experiments, sediment eroded from the scour region was deposited behind the turbine. 


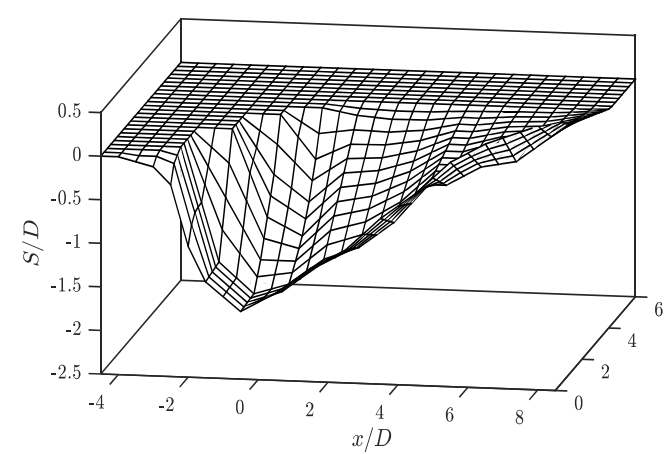

a. tip clearance $=1 \mathrm{H}$

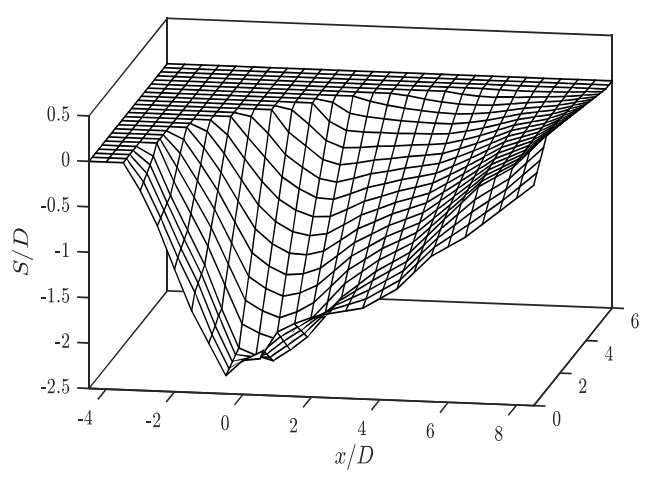

c. tip clearance $=0.5 \mathrm{H}$

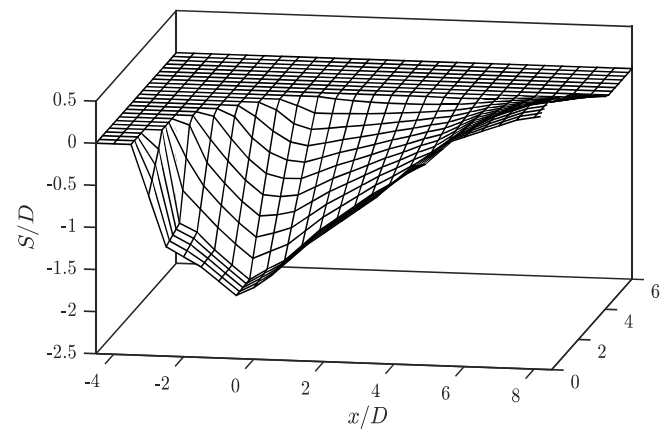

b. tip clearance $=0.75 \mathrm{H}$

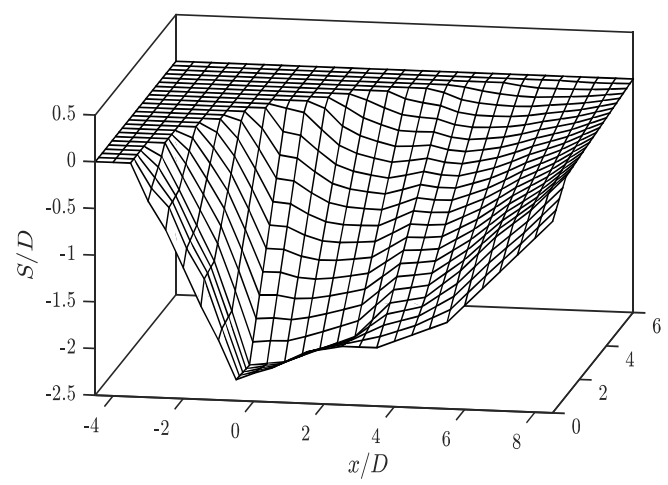

d. tip clearance $=0.25 \mathrm{H}$

Figure 2: 3D surface map of seabed scour at various tip clearance

The scour hole around Darrieus-type tidal current turbine shows the similar pattern on different conditions. The maximum scour depth reaches $2.2 \mathrm{D}$ (at $\mathrm{C} / \mathrm{H}=0.5$ or $\mathrm{C} / \mathrm{H}=0.25$ ). In general, the scour depth increases with the decrease of tip clearance, but it shows some interesting trend in detail. In the case of $\mathrm{C} / \mathrm{H}=1$, the final scour depth after reaching the scour equilibrium is about $1.6 \mathrm{D}$. When the tip clearance decreases to $0.75 \mathrm{H}$, the maximum scour depth is $1.7 \mathrm{D}$, which is approximately like the case of $\mathrm{C} / \mathrm{H}=1$. However, when tip clearance decreases from $0.75 \mathrm{H}$ to $0.5 \mathrm{H}$, the maximum scour depth shows much increase. At $\mathrm{C} / \mathrm{H}=0.5$, the scour depth is $2.2 \mathrm{D}$ after reaching dynamic scoring equilibrium, which is $29.4 \%$ bigger than the case of $\mathrm{C} / \mathrm{H}=0.75$. In the case of $\mathrm{C} / \mathrm{H}=0.25$, the equilibrium scour depth is $2.2 \mathrm{D}$, which is same as the case of $\mathrm{C} / \mathrm{H}=0.5$.

The size of scour hole shows great increase when the tip clearance decreases from $0.75 \mathrm{H}$ to $0.5 \mathrm{H}$, which can be seen in Fig. 3 . The final scour topographies in (a) the case of $\mathrm{C} / \mathrm{H}=0.75$, and (b) the case of $\mathrm{C} / \mathrm{H}=0.5$ are presented in Fig. 3. The pile is the foundation of Darrieus-type tidal current turbine, the operational rotor is installed upon it as shown in Fig.1. The scour hole edge is indicated by white line, and the ridge of dune downstream is marked by black line in Fig.5 (c-d). Two channels like holes are formed on both sides of the dune with longitudinal slopes, which are flatter than the upstream slope. The horizontal extent of scour hole at $\mathrm{C} / \mathrm{H}=0.5$ is much larger than the case of $\mathrm{C} / \mathrm{H}=0.75$. Two branches of dune can be seen in the further downstream. 


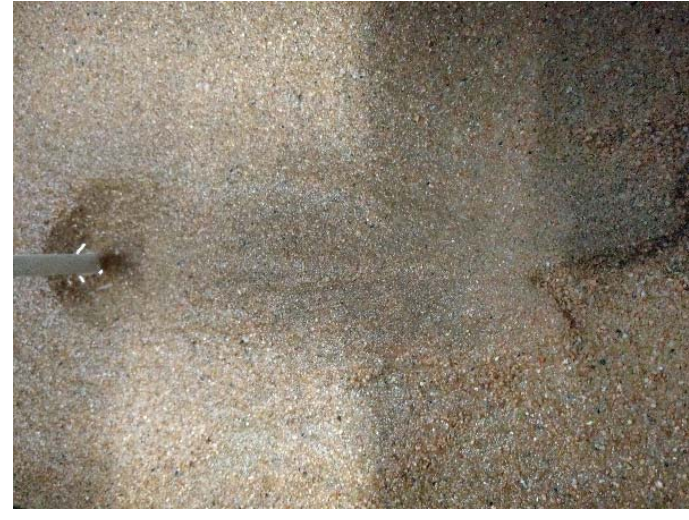

a. tip clearance $=0.75 \mathrm{H}$ (original topography)

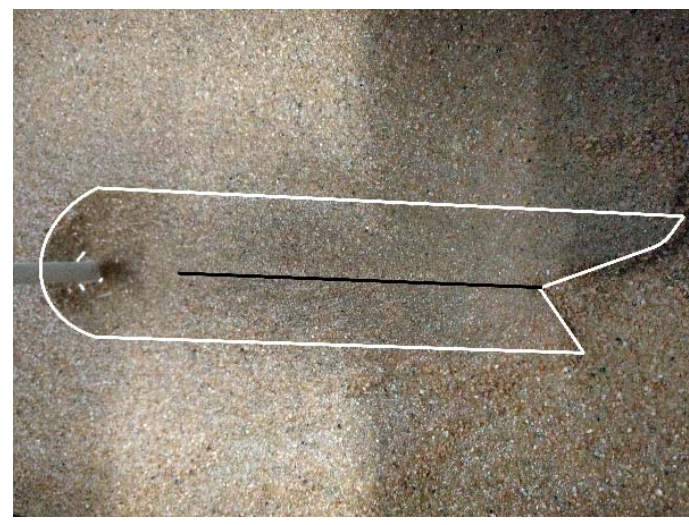

c. tip clearance $=0.75 \mathrm{H}$ (processed topography)

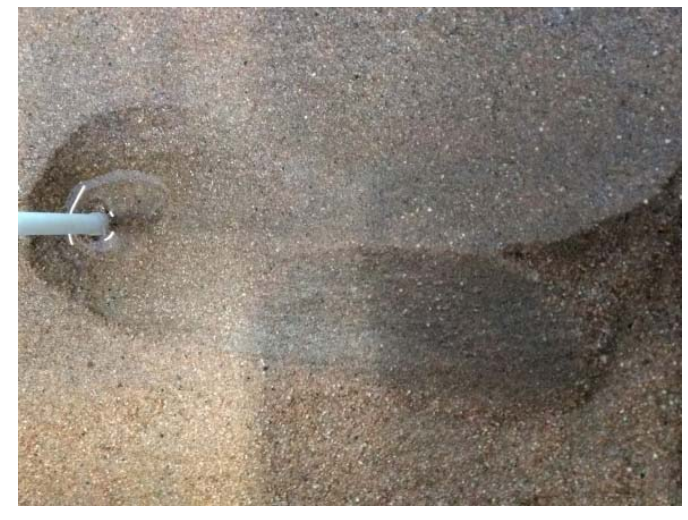

b. tip clearance $=0.5 \mathrm{H}$ (original topography)

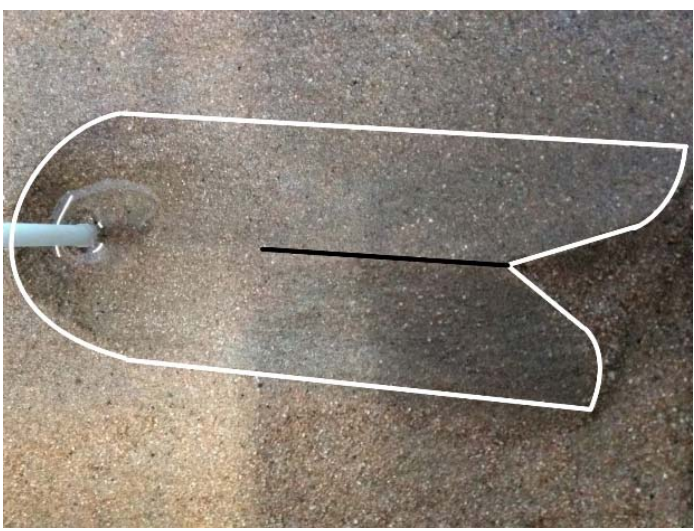

d. tip clearance $=0.5 \mathrm{H}$ (processed topography)

Figure 3: Final scour topography in the case of (a, c) $\mathrm{C} / \mathrm{H}=0.75$ and $(\mathrm{b}, \mathrm{d}) \mathrm{C} / \mathrm{H}=0.5$; (a) and (b) are original topography, (c) and (d) are processed topography. Flow is left to right

The effect of different rotor radius on the scour phenomena was also investigated in the current study. Two other cases of different rotor radius were set up in the current experiment ( $\mathrm{R}=37.4 \mathrm{~mm}$ and $\mathrm{R}=45.9 \mathrm{~mm}$ respectively). The tip clearance was $0.5 \mathrm{H}$, rotational speed and chord length remained unchanged. The final bed topography is shown in Fig. $4(\mathrm{a}-\mathrm{b})$. The maximum scour depth reaches $2.6 \mathrm{D}(\mathrm{R}=37.4 \mathrm{~mm})$, and the minimum scour depth is $2 \mathrm{D}(\mathrm{R}=45.9 \mathrm{~mm})$. Compared to the case of $\mathrm{R}=56.3 \mathrm{~mm}$ as shown in Fig. 2(c), the scour depth in case $\mathrm{R}=37.4 \mathrm{~mm}$ is $18 \%$ deeper, but the scour depth in case $\mathrm{R}=45.9 \mathrm{~mm}$ is $9 \%$ shallower. It is inferred that the different rotor radius could be playing a role: The flow field around Darrieus-type tidal current turbine is affected by the rotor radius. Then the degree of flow acceleration and contraction between turbine and seabed is changed. The relation between scour depth and rotor radius will be discussed in detail in section 4.4. 


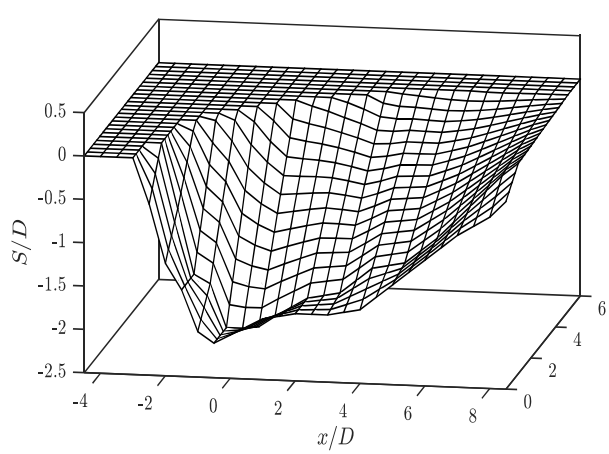

a. $\mathrm{R}=45.9 \mathrm{~mm}$

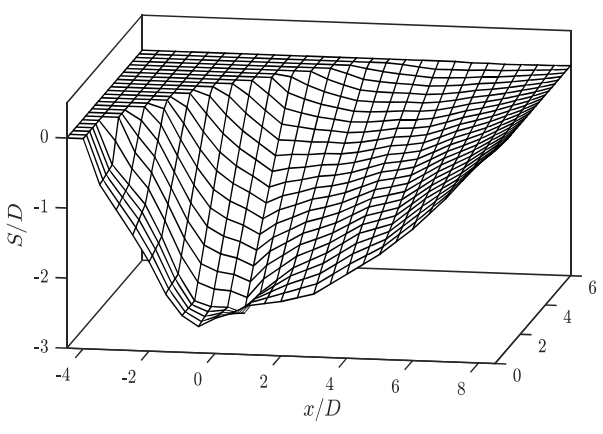

b. $R=37.4 \mathrm{~mm}$

Figure 4: 3D surface map of seabed scour at various rotor radius

\subsection{Horizontal extent of scour hole}

A closer look at horizontal extent of scour hole in different cases is plotted in Fig. 5. The semi-circle in Fig. 5 represents the supporting pile of turbine. Fig. 5 (a) shows the range of scour hole at various tip clearance, and Fig. 5(b) shows the influence of different rotor radius on horizontal extent of scour hole. As shown in Fig. 5(a), the width of scour hole edge is about $3.5 \mathrm{D}$ at $\mathrm{x}=0$ in the cases of $\mathrm{C} / \mathrm{H}=1$ and $\mathrm{C} / \mathrm{H}=0.75$, the size of scour hole shows little change between these two cases. With the decrease of tip clearance from $0.75 \mathrm{H}$ to $0.5 \mathrm{H}$, the scour hole shows great increase. The hole width is about $4 \mathrm{D}$ in the case of $\mathrm{C} / \mathrm{H}=0.5$, which is $14 \%$ larger than the case of $\mathrm{C} / \mathrm{H}=0.75$. However, when the tip clearance decreases from $0.5 \mathrm{D}$ to $0.25 \mathrm{D}$, scour hole width shows a little increase, from 4D to 4.1D. As shown in Fig. 5(b), with different rotor radius, the minimum width of scour hole is $4 \mathrm{D}(\mathrm{R}=45.9 \mathrm{~mm})$ and the maximum width is $4.8 \mathrm{D}$ $(\mathrm{R}=37.4 \mathrm{~mm})$.

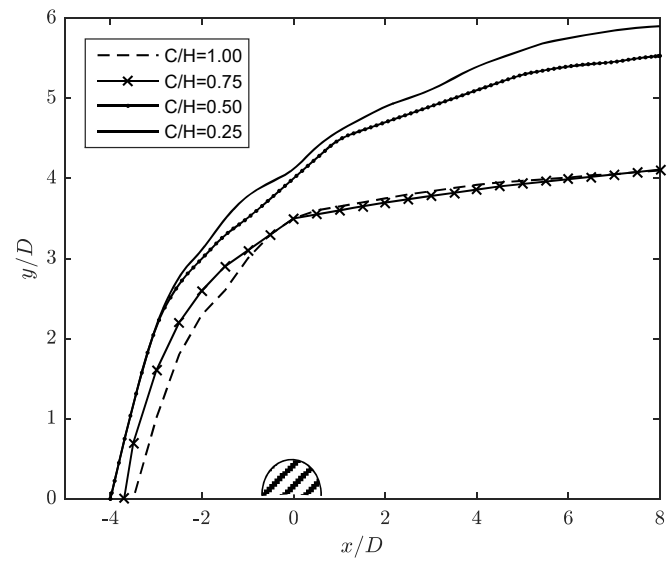

a. Different tip clearance

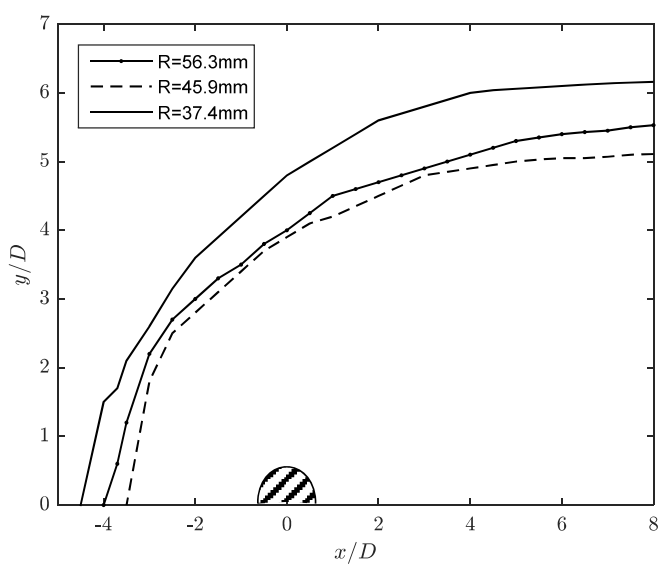

b. Different rotor radius

Figure 5: Half plan view of edge of scour hole around turbine with (a) different tip clearance and (b) different rotor radius

The width of scour hole edge at location $\mathrm{x}=0$ in each case is listed in table 3 . In general, the horizontal extent of scour hole increases with the decrease of tip clearance. Rotor radius can also affect the development of scour hole. 
Table 3: Width of scour hole edge at location $\mathrm{x}=0$

\begin{tabular}{clll}
\hline Case & Rotor radius $(\mathrm{mm})$ & $\mathrm{C} / \mathrm{H}$ & Width/D \\
\hline 1 & 56.30 & 1.00 & 3.5 \\
2 & 56.30 & 0.75 & 3.5 \\
3 & 56.30 & 0.50 & 4.0 \\
4 & 56.30 & 0.25 & 4.1 \\
5 & 45.90 & 0.50 & 3.9 \\
6 & 37.40 & 0.50 & 4.8 \\
\hline
\end{tabular}

\subsection{Scour profiles along the centreline of turbine}

The measured final scour profileS along the centreline of turbine at various tip clearance $(\mathrm{C} / \mathrm{H}=1,0.75,0.5,0.25$, respectively) are presented in Fig.6. In Fig.6 (a), the scour profiles have been normalized by the diameter of supporting pile. The data in the figures reveals that an adverse longitudinal slope is formed downstream, which is flatter than the upstream slope. In the case of $\mathrm{C} / \mathrm{H}=1$ and $\mathrm{C} / \mathrm{H}=0.75$, the horizontal extent of scour hole at streamwise direction is about $5 \mathrm{D}$ downstream. A dune formed behind the turbine can be found. However, the scour profile shows greater scatter in the case of $\mathrm{C} / \mathrm{H}=0.5$ or $\mathrm{C} / \mathrm{H}=0.25$, the size of scour hole is much bigger. The dune cannot be found within the limits of $8 \mathrm{D}$ downstream. The length of scour hole in the streamwise direction is about $8.5 \mathrm{D}$ downstream at $\mathrm{C} / \mathrm{H}=0.5$, and $10 \mathrm{D}$ downstream in the case of $\mathrm{C} / \mathrm{H}=0.25$.

In Fig. 6(b), x-axis was normalized by the length of scour hole in the streamwise direction, $l_{t}$. And y-axis was normalized by the maximum scour depth after reaching equilibrium in each case, $S_{t}$. The dimensionless coordinates $(\hat{x}, \hat{y})$ of the scour hole, where $\hat{x}=x / l_{t}, x=$ horizontal distance from the centre of supporting pile of turbine, and $l_{t}=$ length of scour hole from the supporting pile to the end of the scour hole. $\hat{y}=$ $S / S_{t}, S=$ vertical distance from the undisturbed bed level, and $S_{t}=$ maximum scour depth in each case.

Based on scour profiles at various tip clearance, the scour profiles upstream can be categorized as two conditions: live bed $\operatorname{scour}(\mathrm{C} / \mathrm{H} \leq 0.5)$ and clear water scour $(\mathrm{C} / \mathrm{H}>0.5)$. When $\mathrm{C} / \mathrm{H}>0.5$, the turbine rotor shows little impact on the scour process, the sediment is removed from the scour hole but not supplied by the approaching stream. When $\mathrm{C} / \mathrm{H} \leq 0.5$, the scour phenomenon is live bed scour, the scour hole is continuously fed with the sediment by the approaching stream. Hence the size of scour hole is much bigger. 
(a)
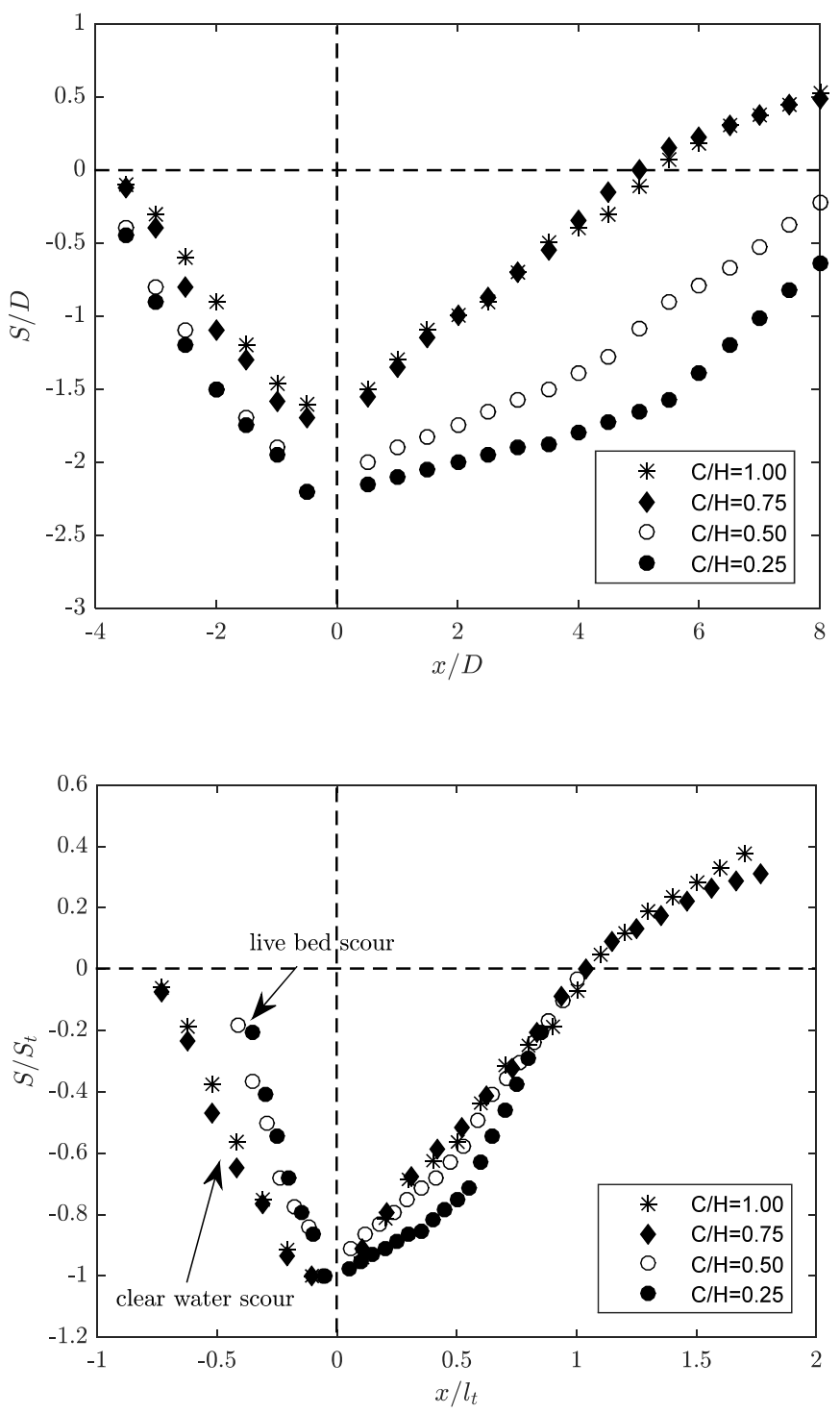

(b)

Figure 6: Scour profiles at various tip clearance along centreline of Darrieus-type tidal current turbine: (a) each axis has been normalized by diameter of supporting pile; (b) horizontal distance was normalized by length of scour hole, $l_{t}$, and vertical distance was normalized by maximum depth of scour hole, $S_{t}$.

In upstream, the data collapse into two curves due to different tip clearance. And all data collapse into one curve downstream. The parameters $S_{t}$ and $l_{t}$ used for proposed model are listed in table 4 . The numerical model to describe the scour profiles will be proposed in section 5 .

Table 4: Parameters in empirical model of scour profiles along centreline of turbine

\begin{tabular}{ccclll}
\hline Case & Rotor radius $(\mathrm{mm})$ & $\mathrm{C} / \mathrm{H}$ & $S_{t} / D$ & $l_{t} / D$ & $l_{t} / S_{t}$ \\
\hline 1 & 56.30 & 1.00 & 1.6 & 4.6 & 2.88 \\
2 & 56.30 & 0.75 & 1.7 & 4.8 & 2.82 \\
3 & 56.30 & 0.50 & 2.2 & 8.5 & 3.86 \\
4 & 56.30 & 0.25 & 2.2 & 10.0 & 4.55 \\
\hline
\end{tabular}




\subsection{Maximum scour depth}

The evolution of scour in time at various tip clearance is plotted in Fig. 7. In each case, the maximum scour depth will not increase after about $150 \mathrm{mins}$, which means the scour process has reached equilibrium. With the decrease of tip clearance, the depth of scour increases more quickly, but the equilibrium time is longer. The least scour depth occurs at $\mathrm{C} / \mathrm{H}=1$, which is $1.6 \mathrm{D}$. The maximum scour occurs in the case of $\mathrm{C} / \mathrm{H}=0.5$ or $\mathrm{C} / \mathrm{H}=0.25$, which is $2.2 \mathrm{D}$. The scour depth at $\mathrm{C} / \mathrm{H}=0.75$ increases about $6.3 \%$ compared to the case of $\mathrm{C} / \mathrm{H}=1$. The final scour depth of cases $\mathrm{C} / \mathrm{H}=0.5$ or $\mathrm{C} / \mathrm{H}=0.25$ is much deeper, which is $29.4 \%$ bigger than the case of $\mathrm{C} / \mathrm{H}=0.75$. This is due to the flow acceleration below turbine and collapse of the slant bed. When the turbine is installed low enough, the scour process is live bed scour, the scour depth will not increase significantly with the continuous decrease of tip clearance.

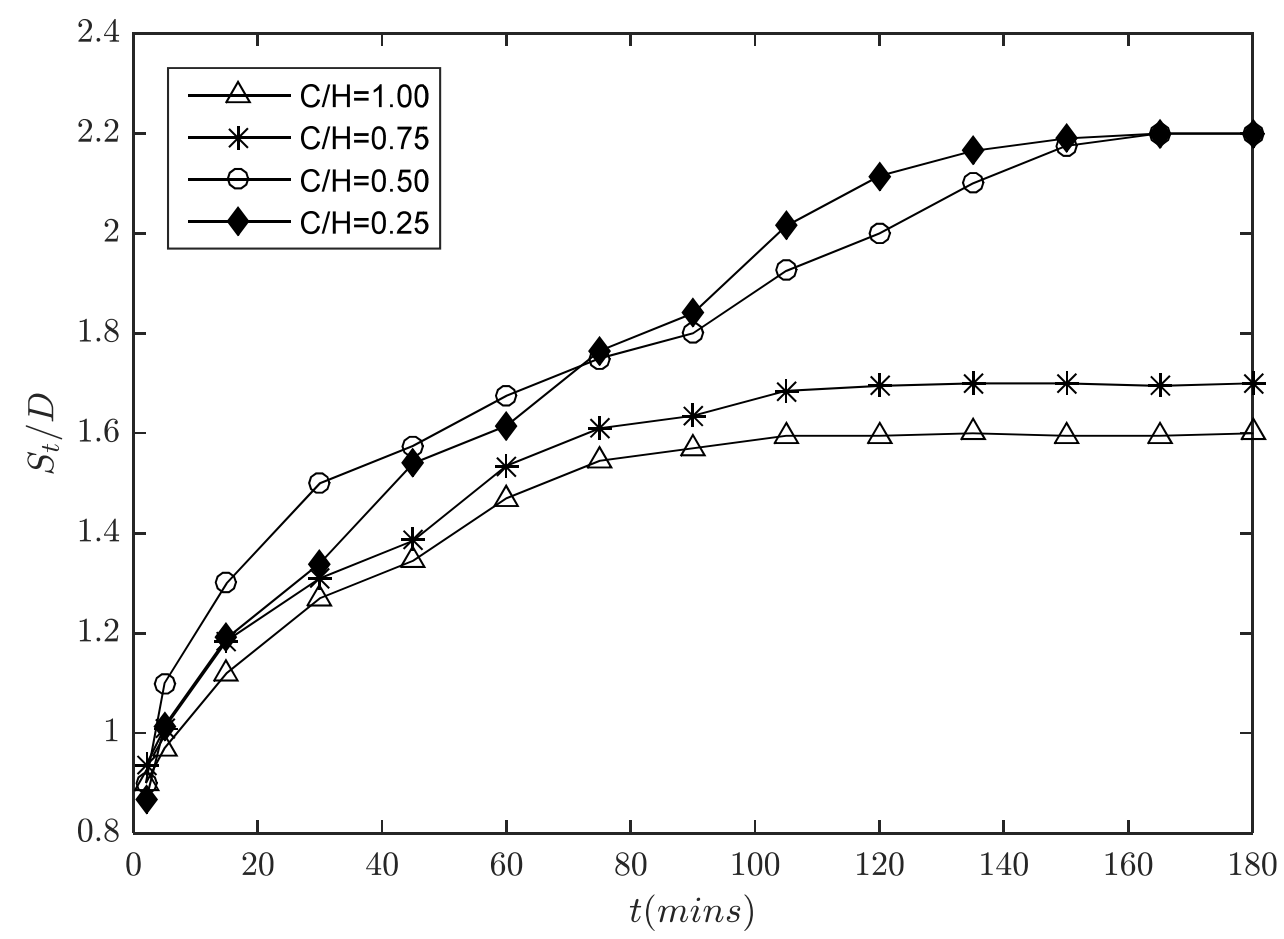

Figure 7: Evolution of maximum scour depth in time at various tip clearance

To find the relation between rotor radius and scour depth, an evolution of scour in time comparison with different radius is plotted in Fig.8. The final scour depth decreases first and then increase against rotor radius. In each case, the scour development has reached equilibrium after $180 \mathrm{mins}$. In the case of $\mathrm{R}=45.9 \mathrm{~mm}$, the scour depth reaches the final equilibrium at about $100 \mathrm{mins}$, which is fastest among all the three cases. The least scour occurred in the case of $\mathrm{R}=45.9 \mathrm{~mm}$, which is $2 \mathrm{D}$. The maximum scour is $2.6 \mathrm{D}$ occurred in the case of $\mathrm{R}=37.4 \mathrm{~mm}$, which is $30 \%$ bigger than the least scour depth. These results reveal that the hydrodynamic performance of Darrieus-type tidal current turbine has great impact on scour depth. 


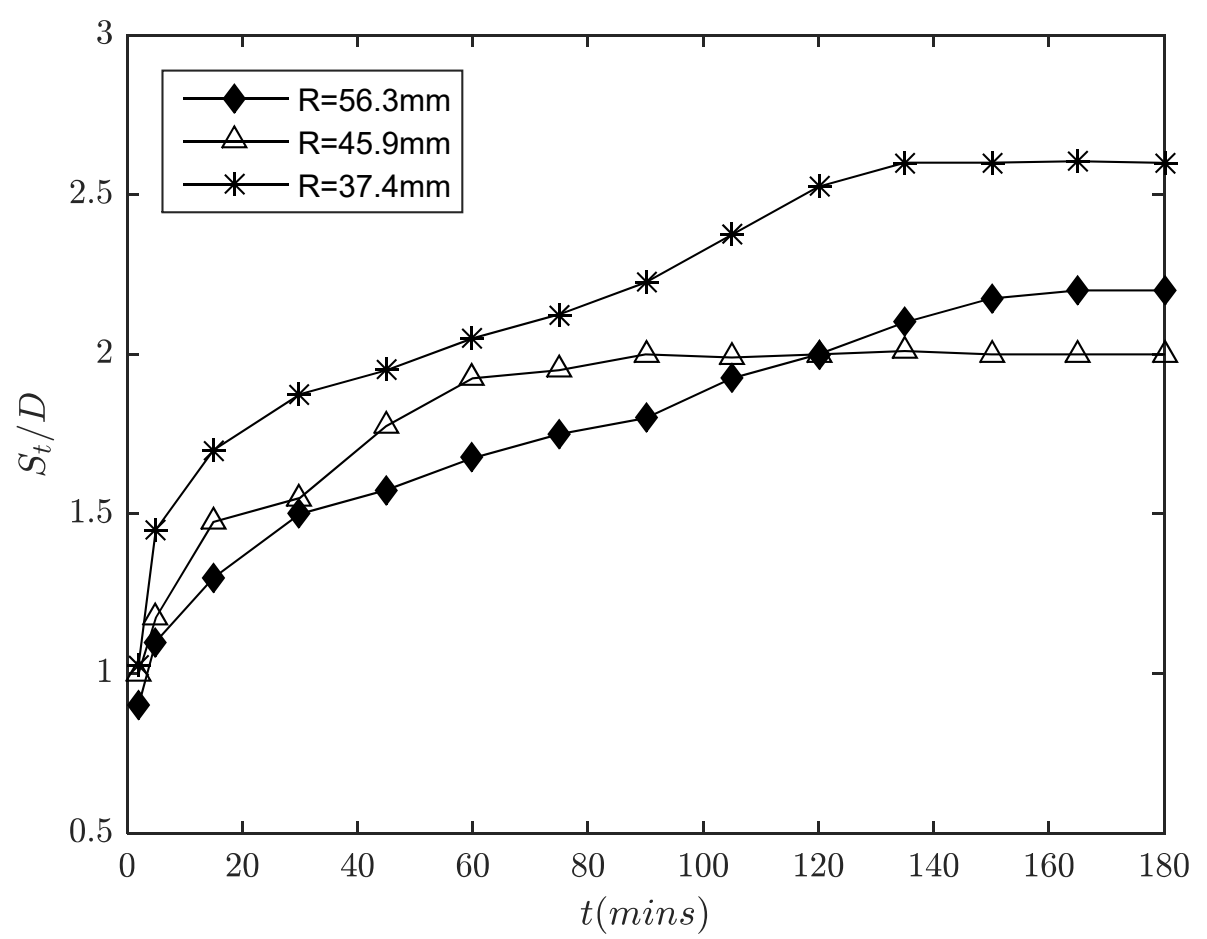

Figure 8: Evolution of maximum scour depth in time with different rotor radius

As mentioned above, the hydrodynamic performance of Darrieus-type tidal current turbine can influence the scour progress. The dimensionless coefficients for power $\left(C_{p}\right)$, as shown in Eq. (1), was calculated by double multiple streamtube model.

$$
C_{P}=\frac{P}{0.5 \rho U_{r}^{2} 2 R H R}
$$

Fig. 9 shows the trend of $C_{p}$ against different rotor radius. The final scour depth and $C_{p}$ against different rotor radius show a contrary trend: with the increase of rotor radius, the scour depth decreases first and then increase, but $C_{p}$ increase first and then decrease. A part of tidal current energy in flow field is captured by the turbine, and $C_{p}$ can be used to investigate the energy extraction efficiency. With the change of $C_{p}$, the rest of energy for seabed scour is different. Meanwhile, the flow passing through turbine can also be disturbed with different $C_{p}$. Then the degree of flow contraction and acceleration below turbine is changed considering law of conservation of mass. Hence the scour hole is deeper at lower $C_{p}$. 


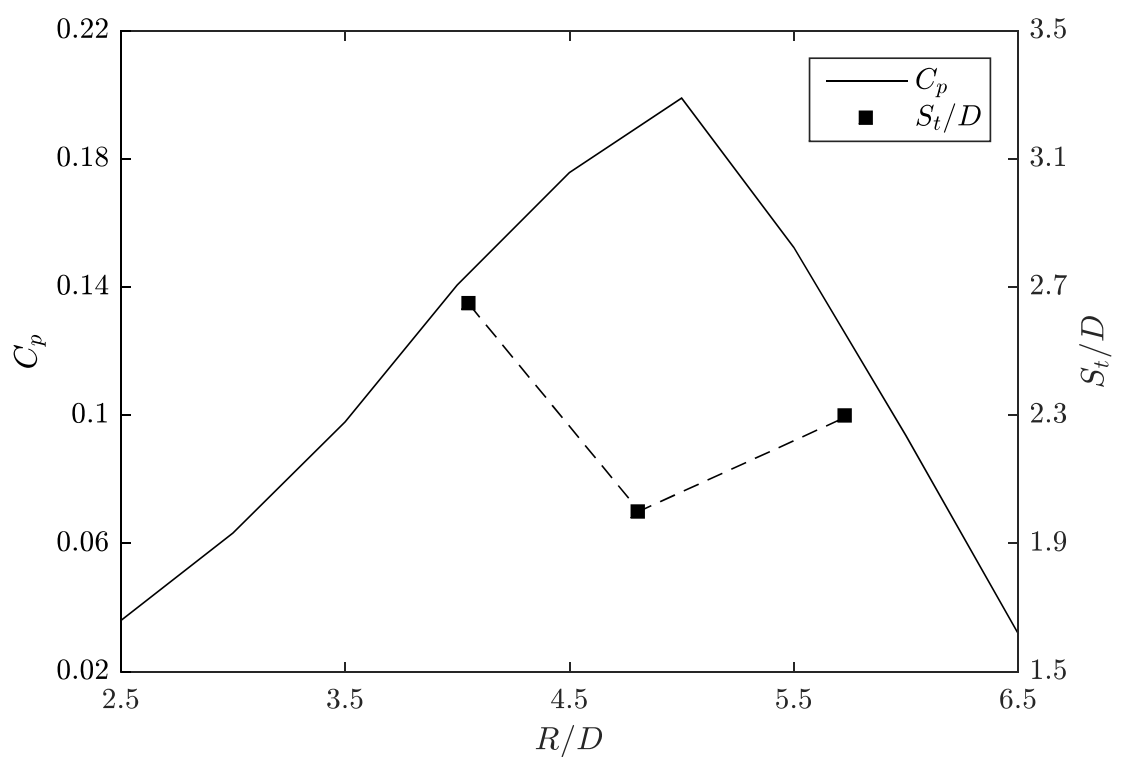

Figure 9: the comparison between Energy extraction efficiency $C_{p}$ and dimensionless scour depth $S_{t} / D$ against different rotor radius

\subsection{Scour process}

Based on the results above, the scour process of Darrieus-type tidal current turbine induced scour will be presented in this section. The seabed scour is mainly developed by the action of horseshoe vortex system, which is much like scour at piles. But the operational rotor makes the phenomenon a little different. The scour process can be categorized as two types: clear water scour $(\mathrm{C} / \mathrm{H}>0.5)$ and live bed scour $(\mathrm{C} / \mathrm{H} \leq 0.5)$. In the process of clear water scour, the sediment is removed from the scour hole but not supplied by the approaching stream. Live bed scour occurs when the scour hole is continuously fed with the sediment by the approaching stream [5].

When the Darrieus-type tidal current turbine is installed high enough $(\mathrm{C} / \mathrm{H}>0.5)$, the scour process is clear water scour. The sediment particles are dislodged by downflow and pulled up along the slope of scour hole by the upward velocity of horseshoe vortex. The dislodged sediment particles are washed out downstream by the arms of the horseshoe vortex. The final equilibrium will be reached when the downflow can no longer remove the particles from the bed.

The evidence of turbine rotor has impact on the scour process. Flow is blocked by the turbine rotor, then the flow acceleration between turbine and seabed occurs due to the flow contraction. Downflow below turbine will be strengthen by the mixing flow. Generally, the hole size has a slight increase with the decrease of tip clearance

However, with the continuous decrease of tip clearance $(\mathrm{C} / \mathrm{H} \leq 0.5)$, the scour will be live bed scour. The sediment particles are dislodged by the action of downflow and are 
pulled up by the action of upward velocity of the horseshoe vortex. In addition, the scour hole is also fed with sediment due to the collapse of seabed. The horizontal and vertical extent of scour hole develops due to the action of downflow along with the sand bed erosion until the equilibrium of scour depth. During this scour process, the horizontal extent of scour hole at lateral direction is about $10-20 \%$ bigger than clear water scour, and scour depth is about $30 \%$ bigger. The dune is formed in the further downstream, and slowly migrates downstream with the development of the scour hole. An adverse longitudinal slope is formed downstream, which is flatter than the upstream slope. With the continuous decrease of tip clearance, the equilibrium scour depth is independent on tip clearance. And the scour depth will no longer increase with the decrease of tip clearance.

Moreover, the scour equilibrium is also affected by the hydrodynamic performance of tidal current turbine. For Darrieus-type tidal current turbine, the flow field around turbine is disturbed due to the operational rotor and become very complicated. A low flow speed area with high pressure occurs behind the turbine along the lateral axis downstream. During the current experiment, the energy extraction efficiencies $C_{p}$ is found to increase firstly and then decrease with the increase of rotor radius, as shown in Fig.11. But the maximum scour depth decreases first and then increase against different rotor radius. $C_{p}$ can be used to investigate the energy extraction efficiency from flow field by Darrieus-type tidal current turbine. The seabed scour develops with the input of energy in flow field, where a part of tidal current energy has been harnessed by the turbine. At lower $C_{p}$, less energy is extracted by the turbine, and more rest energy is used for scour process considering law of conservation of mass. This phenomenon may cause the deeper scour depth.

\section{Empirical model}

An empirical model for Darrieus-type tidal current turbine induced seabed scour will be concluded in this section. This empirical model contains the prediction of scour depth, and the scour profiles along the centreline of Darrieus-type tidal current turbine.

\subsection{Analyses of scour parameters}

There are many parameters which may influence the scouring process. The analysis has been made mainly for the following variables:

For the fluid: $\rho$ density, and $g$ acceleration due to gravity;

For the bed material: $d_{50}$ diameter of sediment and $\rho_{s}$ its density;

For the flow: $h$ the depth and $U_{c}$ the mean velocity of inflow;

For the turbine: $D$ diameter of monopile, $C$ clearance between rotor and seabed and $R$ rotor radius.

Therefore, the scouring depth $S$ depends on nine parameters: 


$$
S_{t}=f_{1}\left(U_{c}, D, C, d_{50}, R, g, \rho, \rho_{s}, h\right)
$$

These parameters may be replaced by the following ones:

$$
S_{t}=f_{2}\left(\frac{U_{c}}{U_{c r}}, \frac{C}{H}, \frac{d_{50}}{D}, \frac{R}{D}, \frac{U_{c}}{(g h)^{0.5}}, \frac{\rho_{s}-\rho}{\rho}\right)
$$

Where $H$ is the height of rotor. It has been assumed therefore that the relative density and relative clearance is of importance. The term $\rho_{s}$ is constant by considering only natural sediments.

The theorem of Vaschy-Buckingham allows us to write:

$$
\begin{array}{cccccc}
\frac{S_{t}}{D}=f_{3}\left(\frac{U_{c}}{U_{c r}}, F_{r}, \frac{d_{50}}{D}, \frac{C}{H}, \frac{R}{D}\right) \\
1 & 2 & 3 & 4 & 5 & 6
\end{array}
$$

Where $F_{r}$ is the densimetric Froude number which is given by

$$
F_{r}=\frac{U_{c}}{(g h)^{0.5}}
$$

The justification for the choice of the dimensionless parameters is the following:

1 The experimental research shows that the scour depth is relate to the diameter of the pier. Since the dimension of horseshoe vortex system is a function of the diameter of the pier;

234 There are classical parameter in the study of local scour at piers.

56 These ratios show the impact of Darrieus-type tidal current turbine on the scour depth.

This research aims to investigate the scour depth of Darrieus-type tidal current turbine induced scour and propose empirical equations to predict the scour depth. Parameters 2-4 have been studied by many researchers for scour around piers. Parameters 5 and 6 should be two important variables to represent the effect of turbine. After applying the Buckingham $\pi$ theorem, the correction factor for Darrieus-type tidal current turbine can be obtained as follows:

$$
K_{t}=f_{4}\left(\frac{R}{D}, \frac{C}{H}\right)
$$




\subsection{Empirical model of scour depth}

\subsubsection{Influence of tip clearance}

To investigate the impact of tip clearance on the scour depth of Darrieus-type tidal current turbine induced scour, the final scour depth of scour around single pile without rotor was tested. The maximum scour depth is $1.45 \mathrm{D}$, which is $9 \%$ less than Darrieustype tidal current turbine induced scour in the case of $\mathrm{C} / \mathrm{H}=1$. The comparison of scour depths with different tip clearance is shown in Fig. 10. The dashed line shows the scour depth of single pile without rotor in the current experimental conditions.

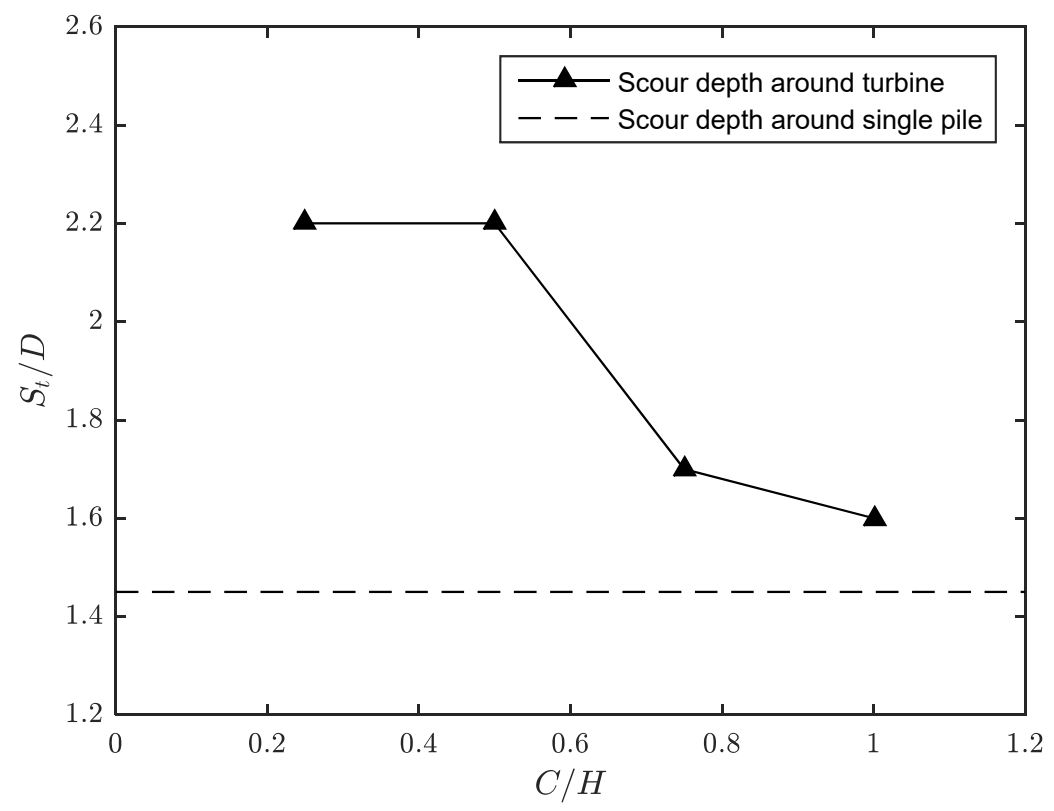

Figure 10: The scour depth of Darrieus-type tidal current turbine induced scour against different tip clearance, the dashed line shows scour depth around single pile

The final depth of Darrieus-type tidal current turbine induced scour increases with the decrease of tip clearance, which can be seen in Fig. 11. The scour depth around turbine is deeper than scour around pile. This may due to the flow acceleration and contraction below the turbine. The increments of scour depth between scour around pile and Darrieus-type tidal current turbine are listed in table 5.

Table 5: Comparison of scour depth between scour around turbine and single pile

\begin{tabular}{lllll}
\hline Case & Rotor radius $(\mathrm{mm})$ & $\mathrm{C} / \mathrm{H}$ & $\mathrm{S} / \mathrm{D}$ & Increment $(\%)$ \\
\hline 1 & 56.30 & 1.00 & 1.6 & 9.9 \\
2 & 56.30 & 0.75 & 1.7 & 16.8 \\
3 & 56.30 & 0.50 & 2.2 & 51.3 \\
4 & 56.30 & 0.25 & 2.2 & 51.3 \\
5 & 45.90 & 0.50 & 2.0 & 37.5 \\
6 & 37.40 & 0.50 & 2.6 & 78.9 \\
\hline
\end{tabular}


There is a significant increase in scour depth around Darrieu-type tidal current turbine when compared to scour around single pile. In the current experiments, the maximum increase of scour depth is about $78.9 \%$, and the minimum increase is about $9.9 \%$. The empirical model for scour depth can be proposed based on the researches of scour around single pile. Numerous equations have been proposed to estimate the scour depth around piles in the previous researches, as shown in table 6.

Table 6: summary of equations for predicting scour around piles.

\begin{tabular}{llc}
\hline Empirical equations & Notation & $S / D$ \\
\hline Neill [6] & $K_{S}$ is the correction factor of pier shape. In the & 1 \\
$\frac{S}{D}=K_{s}$ & current experiment, $K_{S}=1$. &
\end{tabular}

$$
\begin{aligned}
& \text { Breusers et al.[7] } \\
& \frac{S}{D}=1.5 K_{s} K_{\theta} K_{b} K_{d} \tanh \left(\frac{H}{D}\right) \\
& \text { Richardson and Davis[8] } \\
& \frac{S}{D}=2.0 K_{s} K_{\theta} K_{b} K_{d} K_{w}\left(\frac{H}{D}\right)^{0.35} F^{0.43}
\end{aligned}
$$$$
K_{b} \text { is the correction factor for bed condition, }
$$$$
K_{d} \text { is the correction factor for size of bed }
$$$$
\text { material. In the current experiment, } K_{b}=0.91 \text {, }
$$$$
K_{d}=1.1 \text {. }
$$

$K_{\theta}$ is the correction factor for flow angle of attack, $F_{r}$ is the Froude number of incoming flow. $K_{w}$ is the correction factor for pier width or pile diameter. In the current experiment, $F_{r}=$ $0.13, K_{\theta}=1 . K_{w}$ can be ignored due to the ratio of depth of flow to pier width is more than 0.8 .

$\mathrm{K}=$ empirical expressions accounting for the various influences on the scour depth; $K_{y W}$ = depth size; $K_{I}=$ flow intensity; $K_{D}=$ sediment size; and $K_{G}=$ channel geometry. In the current experiment, $K_{y W}=2.4, K_{I}=$ $0.91, K_{d}=0.75, K_{G}=1$.

$$
\frac{S}{D}=K_{y W} K_{I} K_{D} K_{s} K_{\theta} K_{G}
$$

$K_{c}$ is the correction factor for tip clearance, and $K_{r}$ is the correction factor for rotor 
radius. The correction factor for Darrieus-type tidal current turbine $K_{t}$ can be formed as Eq. (8).

$$
K_{t}=K_{c} K_{r}
$$

Based on the experimental results, the influence of tip clearance on scour depth can be investigated. In the actual engineering of tidal current turbine, the tip clearance is about $0.5 \mathrm{H}$. $K_{t}$ is assumed to be 1 at $\mathrm{C} / \mathrm{H}=0.5$. Then the correction factor for normalized tip clearance can be described as follow:

a. $\mathrm{C} / \mathrm{H}>1$, the impact of turbine is not significant. The correction factor for turbine remained to be constant. $K_{c}$ is same as the case of $\mathrm{C} / \mathrm{H}=1$.

$$
K_{c}=0.727
$$

b. $0.5<\mathrm{C} / \mathrm{H} \leq 1$, the impact of turbine increases with the decrease of tip clearance. The scour process is still clear water scour. With the decrease of tip clearance, the strength of downflow increase due to flow contraction and acceleration below turbine. In these conditions, the impact of tip clearance on scour depth can be described by quadratic function.

$$
K_{c}=(C / H-1)^{2}+0.727
$$

c. $\mathrm{C} / \mathrm{H} \leq 0.5$, the correction factor for turbine remained constant. In this case, the scour process is live bed scour, and the equilibrium depth of scour hole will not increase with the continuous decrease of tip clearance.

$$
K_{c}=1
$$

The fitting curve of $K_{c}$ and experimental data is presented in Fig. 11. $S_{0}$ is scour depth in the case of $\mathrm{C} / \mathrm{H}=0.5$.

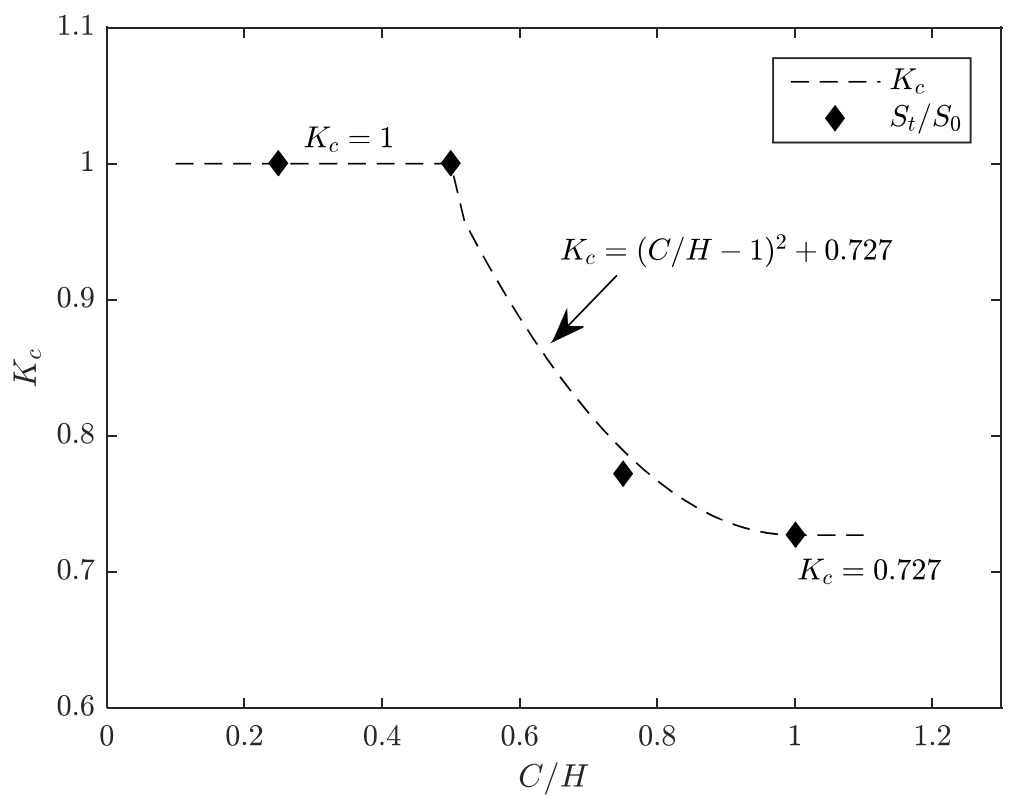

Figure 11: The correction factor for tip clearance $K_{C}$ 


\subsubsection{Influence of rotor radius}

As shown in Fig.12, the scour depth decreases first and then increase with the increase of rotor radius. In the current experiment, the maximum scour depth is $2.6 \mathrm{D}$ at $\mathrm{R}=37.4 \mathrm{~mm}$, and minimum scour depth is $2 \mathrm{D}$ at $\mathrm{R}=45.9 \mathrm{~mm}$. The tip clearance remained $0.5 \mathrm{H}$ in each case, which is close to actual projects of Darrieus-type tidal current turbine. The seabed scour reaches minimum depth when the rotor radius is close to $\mathrm{R}=45.9 \mathrm{~mm}$ and increases with the deviation from that radius. However, the scour has maximum depth instead of keeping increasing. Based on these analysis, the Gaussian probability distribution is modified to fit experimental data of scour depth against different rotor radius. The influence of rotor radius on the scour depth resulted in a relation of the form:

$$
K_{r}=\frac{S_{\max }-\left(S_{\max }-S_{\min }\right) e^{\left[-((R-u) / D)^{2} /\left(2 \sigma^{2}\right)\right]}}{S_{0}}
$$

Where $u$ is the radius at which the minimum scour depth is obtained. As shown in section 4.4, $C_{P}$ is changed with different rotor radius, and the scour depth shows contract trend with $C_{P}$ against rotor radius. At about $R=4.96 \mathrm{~mm}$, the maximum $C_{P}$ is reached. Hence $u=4.96$. And $\sigma$ is scale parameter of Eq. (12). Compared to experimental data, $\sigma$ can be substituted as $0.6, S_{\max }=$ maximum scour depth against different rotor radius, and $S_{\min }=$ minimum scour depth against different rotor radius. $S_{\max }$ and $S_{\min }$ are estimated based on experimental data. $K_{r}$ can be obtained as following:

$$
K_{r}=1.213-0.35 e^{\left[-(R / D-4.96)^{2} / 0.72\right]}
$$

The fitting curve of $K_{r}$ and experimental data is presented in Fig.12. $K_{r}$ is assumed to be 1 at $\mathrm{R}=56.3 \mathrm{~mm}$.

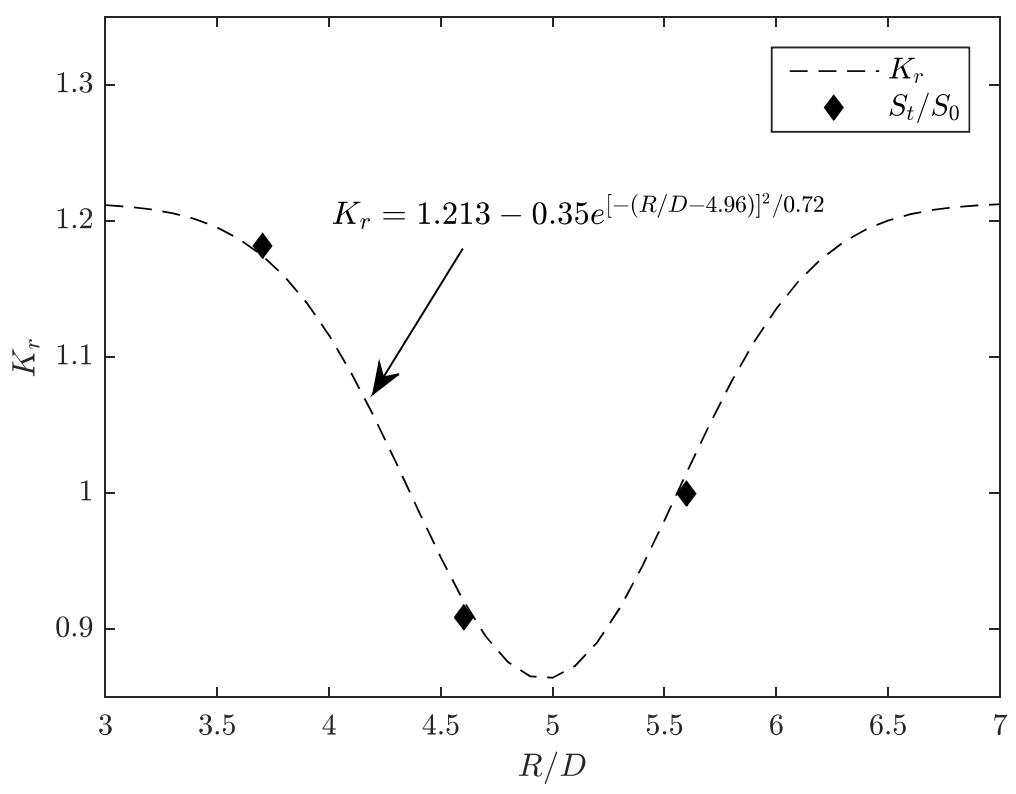

Figure 12: The correction factor for rotor radius $K_{r}$ 
To sum, the empirical equations for predicting scour depth around turbine are listed in table 7, which are obtained by adding a correction factor $K_{t}$ to the equations for scour around piles. In addition, each equation of pile induced scour should be adjusted by multiplying a constant $m$ to ensure the predicted scour depth is equal to the turbine induced scour in the case of $\mathrm{C} / \mathrm{H}=0.5$.

Table 7: Empirical equations for predicting scour around turbine

\begin{tabular}{lll}
\hline $\begin{array}{l}\text { Empirical equations for predicting } \\
\text { scour around pile }\end{array}$ & $m$ & $\begin{array}{l}\text { Empirical equations for predicting } \\
\text { scour around turbine }\end{array}$ \\
\hline$\frac{S}{D}=K_{s}$ & 2.2 & $\frac{S_{t}}{D}=2.2 K_{s} K_{t}$ \\
$\frac{S}{D}=1.5 K_{s} K_{\theta} K_{b} K_{d} \tanh \left(\frac{H}{D}\right)$ & 1.47 & $\frac{S_{t}}{D}=2.205 K_{s} K_{\theta} K_{b} K_{d} K_{t} \tanh \left(\frac{H}{D}\right)$ \\
$\frac{S}{D}=2.0 K_{s} K_{\theta} K_{b} K_{d} K_{w}\left(\frac{H}{D}\right)^{0.35} F^{0.43}$ & 0.82 & $\frac{S_{t}}{D}=1.64 K_{s} K_{\theta} K_{b} K_{d} K_{w} K_{t}\left(\frac{H}{D}\right)^{0.35} F r^{0.43}$ \\
$\frac{S}{D}=K_{y W} K_{I} K_{d} K_{s} K_{\theta} K_{G}$ & 1.34 & $\frac{S_{t}}{D}=1.32 K_{y W} K_{I} K_{d} K_{s} K_{\theta} K_{G} K_{t}$
\end{tabular}

In Eqs.(14-17), $K_{t}$ is the correction factor for Darrieus-type induced tidal current turbine, in which

$$
K_{t}=K_{c} K_{r}
$$

Where

$$
\begin{array}{ll}
K_{c}=0.727 & \text { for } C / H>1 \\
K_{c}=(C / H-1)^{2}+0.727 & \text { for } 0.5<C / H \leq 1 \\
K_{c}=1 & \text { for } C / H \leq 0.5
\end{array}
$$

And

$$
K_{r}=1.213-0.35 e^{\left[-(R / D-4.96)^{2} / 0.72\right]}
$$

The overall comparison between the computed and observed maximum scour depth is presented in Fig. 13. The results provided a great correlation, with an $R^{2}$ of 0.9894 . 


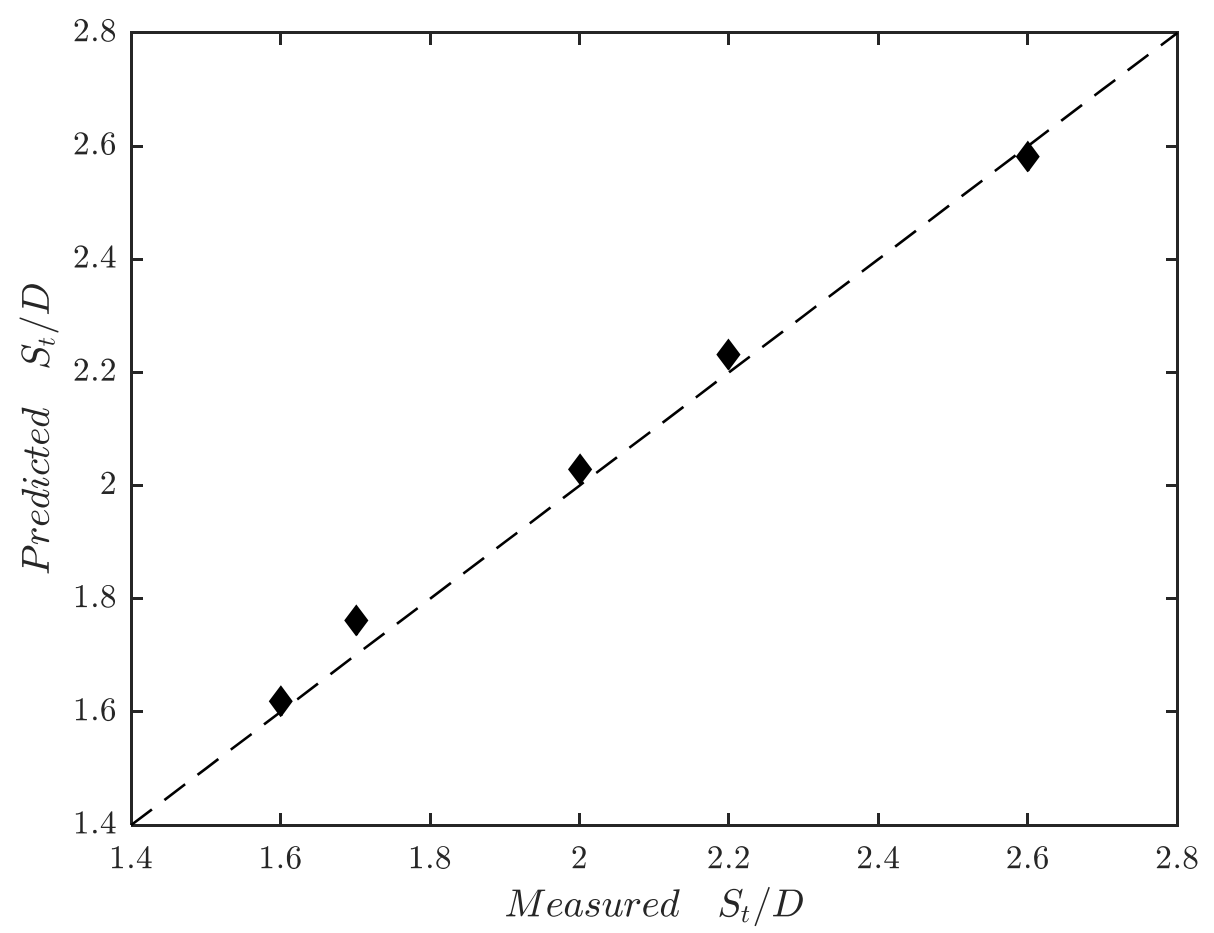

Figure 13: Comparison between measured and predicted maximum scour depth

\subsection{Scour profiles along centreline}

The schematic diagram of scour profiles along centreline of turbine is discussed in section 4.3, an empirical model for scour profiles will be proposed in this section. As plotted in Fig. 14, the data collapse into two curves due to different scour types upstream, and all data collapse into one curve downstream. To describe the scour profiles along the centreline of turbine, the measured dimensionless scour profiles are compared with three independently polynomials as follows:

$$
\begin{aligned}
& \hat{y}(\hat{x}>0)=a_{0}+a_{1} \hat{x}+a_{2} \hat{x}^{2}+a_{3} \hat{x}^{3} \\
& \hat{y}(\hat{x} \leq 0)=b_{0}+b_{1} \hat{x}+b_{2} \hat{x}^{2}, \text { for live bed scour }(\mathrm{C} / \mathrm{H} \leq 0.5) \\
& \hat{y}(\hat{x} \leq 0)=c_{0}+c_{1} \hat{x}+c_{2} \hat{x}^{2}, \text { for clear water scour }(\mathrm{C} / \mathrm{H}>0.5)
\end{aligned}
$$

Where $\hat{x}=x / l_{t}$, and $\hat{y}=S / S_{t}$. In which $a_{0-3}, b_{0-2}, c_{0-2}$ are coefficients. The scour profiles downstream can be fitted by cubic polynomials, and scour profiles upstream is more like second-order equations. In Eq.(19), two boundary conditions should be satisfied, which are as follows: (1) at $\hat{x}=0, \hat{y}=-1$; (2) at $\hat{x}=1, \hat{y}=0$. Similarly, the coefficients $b_{0-2}$ and $c_{0-2}$ related to Eq.(20) and Eq.(21), which depict the scour profiles upstream, should agree with the following boundary conditions: (1) at $\hat{x}=$ $0, \hat{y}=-1 ;(2)$ at $\hat{x}=0, \mathrm{~d} \hat{y} / d \hat{x}=0$. Then the empirical equations for scour profiles along the centerline of turbine can be obtained as follows: 
$\hat{y}(\hat{x}>0)=-1+0.8 \hat{x}+0.5 \hat{x}^{2}-0.3 \hat{x}^{3}$

$\hat{y}(\hat{x} \leq 0)=-1+5.2 \hat{x}^{2}$, for live bed scour $(\mathrm{C} / \mathrm{H} \leq 0.5)$

$\hat{y}(\hat{x} \leq 0)=-1+1.8 \hat{x}^{2}$, for clear water scour $(\mathrm{C} / \mathrm{H}>0.5)$

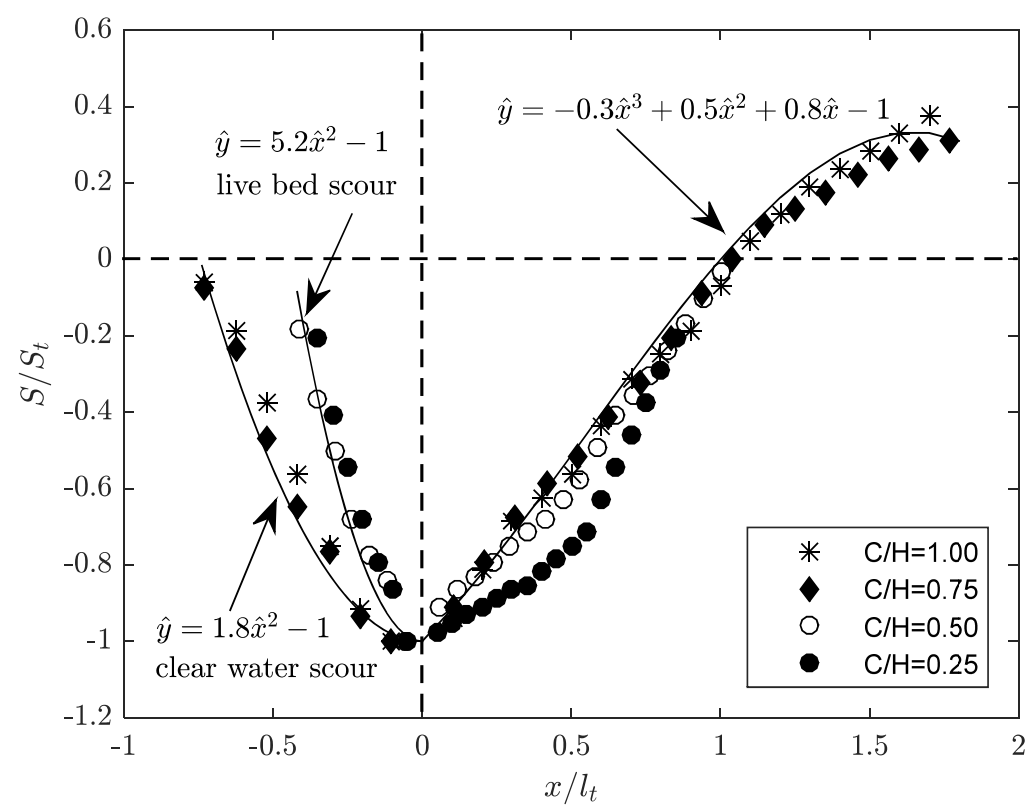

Figure 14: empirical model for scour profiles along centerline of turbine

$S_{t}$ can be obtained by the empirical model as listed in table 7 , and $l_{t}$ is mainly influenced by the tip clearance in each case. In the case of $0.25 \leq \mathrm{C} / \mathrm{H}<0.75, l_{t}$ can be fitted by linear function against tip clearance. And $l_{t}$ is suggested as listed in table 8 .

Table 8: Parameters in empirical model of scour profiles along centreline of turbine

\begin{tabular}{ll}
\hline Case & $l_{t} / D$ \\
\hline $\mathrm{C} / \mathrm{H} \geq 1$ & 4.6 \\
$0.75 \leq \mathrm{C} / \mathrm{H}<1$ & 4.8 \\
$0.25 \leq \mathrm{C} / \mathrm{H}<0.75$ & $12.6-10.4 \cdot \frac{C}{H}$ \\
$0<\mathrm{C} / \mathrm{H}<0.25$ & 10.0 \\
\hline
\end{tabular}

To ascertain the general applicability of this empirical model, the experimental data of Ming Zhao [29] and model of topwidth of scour hole proposed by Richardson and Davis [8] of scour at piles were used for comparison, as shown in Fig. 15. Richardson and Davis suggest that topwidth of scour hole is twice than the maximum scour depth for scour at bridges, which is $30 \%$ less than the case of clear water scour around Darrieustype tidal current turbine in the current experiment (at $\mathrm{C} / \mathrm{H}=0.75$, scour depth is $1.7 \mathrm{D}$, $\left.l_{t} / S_{t}=2.82\right)$. However, the dune formed downstream is ignored in their model. In 
Ming Zhao's experiment, $d_{50}=0.4 \mathrm{~mm}$, hence the maximum scour depth of their experiment (1.25D) is less than the current experiment (at $\mathrm{C} / \mathrm{H}=0.75$, scour depth is 1.7D). However, the scour profiles along the centreline in streamwise direction in Ming Zhao's experiment shows great agreement with the proposed model, as shown in Fig.15(b).

(a)

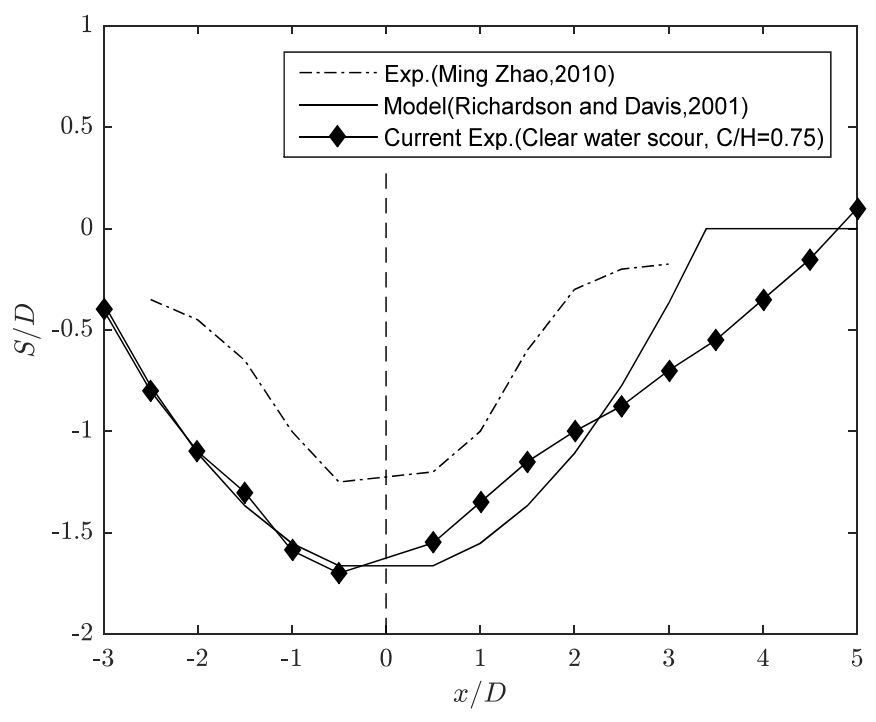

(b)

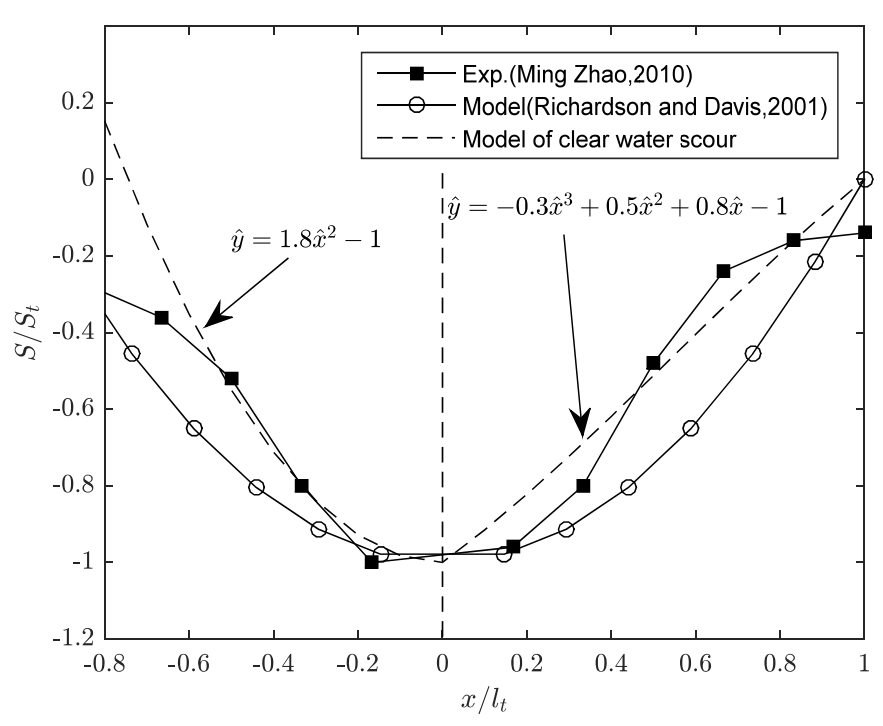

Figure 15: Comparison of Ming Zhao's (2010) data, Richardson and Davis's (2001) model of topwidth of scour hole around piles, the current experimental data for Darrieus-type tidal current turbine induced scour and the proposed model for clear water scour.

\subsection{Empirical model}

Based on the analysis in section 4, the empirical model of scour profile for Darrieustype tidal current turbine induced seabed scour is presented in Fig.16. $S_{t}$ can be predicted by each numerical equation in Eqs.(14-17) listed in table 7, and correction factor for Darrieus-type tidal current turbine $K_{t}$ is calculated by Eq.(18) as shown in 
section 5.2. The numerical model for the shape of scour hole along centreline of turbine can be obtained through Eq.(22) as shown in section 5.3.

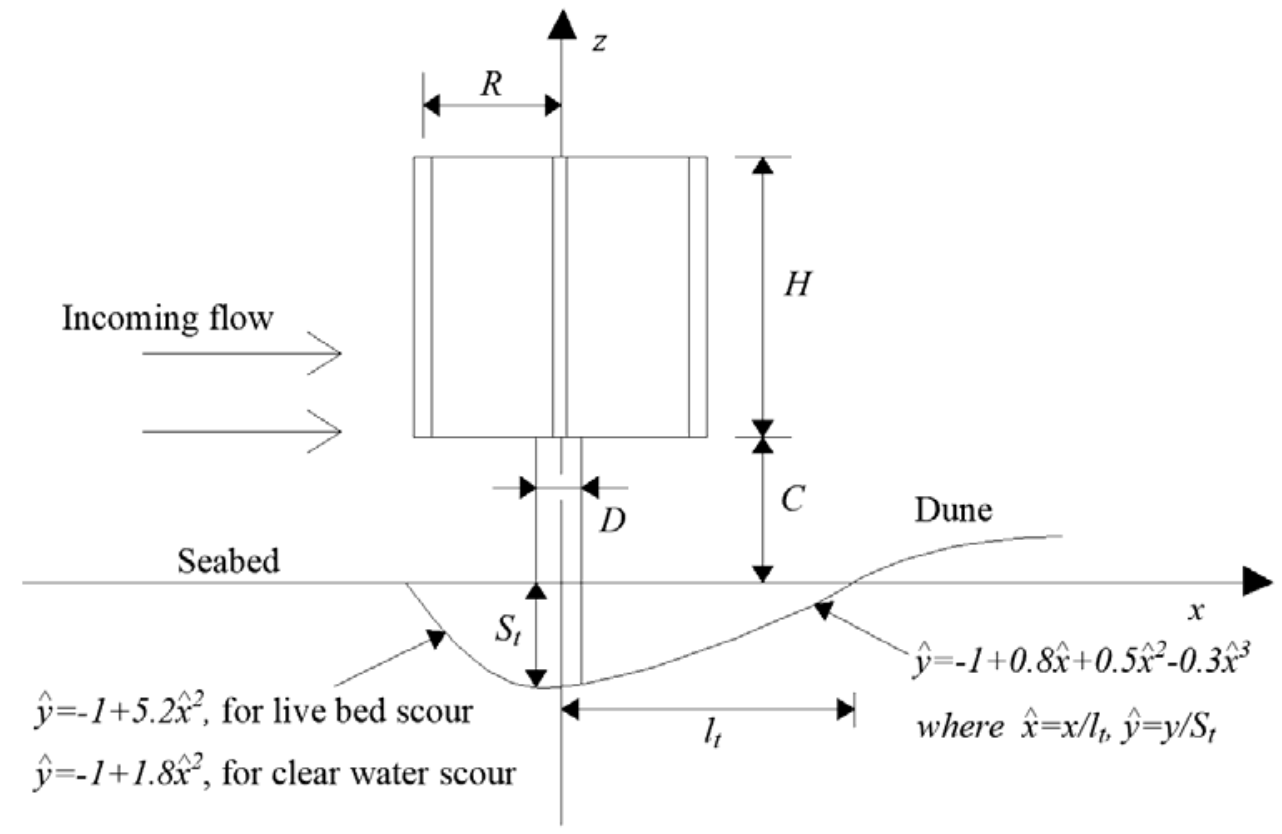

Figure 16: Empirical model for Darrieus-type tidal current turbine induced seabed scour

\section{Conclusion}

The presence of rotor amplifies the horizontal and vertical extent of Darrieus-type tidal current turbine induced seabed scour. The scour depth increases due to the flow acceleration and contraction between turbine and seabed. The tip clearance plays the most important role in affecting the scour depth. Normally, the scour depth increases with the decrease of tip clearance. However, when the tip clearance is low enough, the scour process become live bed scour, and scour depth will not increase significantly with the continuous decrease of tip clearance. In addition, the scour depth increases firstly and then decrease with the increase of rotor radius. It means the hydrodynamic performance of Darrieus-type tidal current turbine can also affect the scour process. Based on the experimental data, the effort in proposing an empirical model to predict the Darrieus-type tidal current turbine induced seabed scour was a success. The contributions made through this study are:

1. The value and location of maximum scour depth of Darrieus-type tidal current turbine at various tip clearance and rotor radius are obtained. The impact of turbine rotor on the scour process has been discussed. In the current experiment, the maximum scour depth reached $2.6 \mathrm{D}$ in the case of $\mathrm{C} / \mathrm{H}=0.5$ and $\mathrm{R}=37.4 \mathrm{~mm}$, while the minimum scour depth is $1.6 \mathrm{D}$ in the case of $\mathrm{C} / \mathrm{H}=1$. The maximum scour depth is about $80 \%$ bigger than scour around single pile. The maximum scour depth happened at site of supporting pile, at location about $\mathrm{x} / \mathrm{D}=-0.5, \mathrm{y} / \mathrm{D}=-0.5$. A dune is formed behind turbine and slowly migrated downstream with the development of the scour hole, and the maximum height of the dune is about $1 \mathrm{D}$. 
2. The empirical model for Darrieus-type tidal current turbine induced seabed scour was proposed. Firstly, a correction factor for Darrieus-type tidal current turbine considering the effect of tip clearance and rotor radius was proposed.

$$
K_{t}=K_{c} K_{r}
$$

Where

$$
\begin{array}{ll}
K_{c}=0.727 & \text { for } C / H>1 \\
K_{c}=(C / H-1)^{2}+0.727 & \text { for } 0.5<C / H \leq 1 \\
K_{c}=1 & \text { for } C / H \leq 0.5
\end{array}
$$

And

$$
K_{r}=1.213-0.35 e^{\left[-(R / D-4.96)^{2} / 0.72\right]}
$$

The numerical equations to predict scour depth were proposed by adding the correction factor $K_{t}$ based on empirical equations for scour around piles.

Secondly, the empirical model for scour profiles along the centreline of turbine was proposed as follows:

$$
\begin{aligned}
& \hat{y}(\hat{x}>0)=-1+0.8 \hat{x}+0.5 \hat{x}^{2}-0.3 \hat{x}^{3} \\
& \hat{y}(\hat{x} \leq 0)=-1+5.2 \hat{x}^{2}, \text { for live bed } \operatorname{scour}(\mathrm{C} / \mathrm{H} \leq 0.5) \\
& \hat{y}(\hat{x} \leq 0)=-1+1.8 \hat{x}^{2}, \text { for clear water scour }(\mathrm{C} / \mathrm{H}>0.5)
\end{aligned}
$$

In future research works, it is suggested to investigate the influence of turbine geometry, turbine hydrodynamic performance with more details on Darrieus-type tidal current turbine induced seabed scour.

\section{Acknowledgements}

The current research was supported by the fund of Beiyang Scholar Foundation and State Key Laboratory of Hydraulic Engineering Simulation and Safety from Tianjin University, People's Republic of China. The authors wish to extend their gratitude to Queen's University Belfast, University of Plymouth, University of Oxford, Dalian University of Technology, University of Malaya, Universiti Teknologi Malaysia and Southern University College for the previous supports. 


\section{List of symbols}

\begin{tabular}{|c|c|}
\hline$R$ & rotor radius \\
\hline$H$ & height of turbine rotor \\
\hline$c$ & chord length of turbine rotor \\
\hline$C$ & turbine tip clearance \\
\hline$D$ & diameter of supporting pile \\
\hline$\omega$ & rotational speed of turbine \\
\hline$h$ & flow depth \\
\hline$Q_{w}$ & flow discharge \\
\hline$b$ & channel width \\
\hline$d_{50}$ & mean sediment grain diameter \\
\hline$F_{r}$ & Froude number of incoming flow \\
\hline$U_{c}$ & depth-averaged current speed \\
\hline$U_{c r}$ & threshold depth-averaged current speed \\
\hline$x$ & longitudinal (streamwise) direction \\
\hline$y$ & lateral direction \\
\hline$z$ & vertical direction \\
\hline$S$ & scour depth at different locations \\
\hline$S_{t}$ & maximum scour depth \\
\hline$l_{t}$ & length of scour hole from foundation to the end of scour hole \\
\hline$P$ & output power of turbine \\
\hline$t$ & time \\
\hline$\rho$ & density of fluid \\
\hline$C_{p}$ & dimensionless coefficients for power \\
\hline$g$ & acceleration due to gravity \\
\hline$\rho_{s}$ & density of sediment \\
\hline$K_{t}$ & correction factor for Darrieus-type tidal current turbine \\
\hline$K_{r}$ & correction factor for rotor radius \\
\hline$K_{c}$ & correction factor for tip clearance \\
\hline$K_{s}$ & correction factor for pier shape \\
\hline$K_{b}$ & correction factor for bed condition \\
\hline$K_{d}$ & correction factor for size of bed material \\
\hline$K_{\theta}$ & correction factor for flow angle of attack \\
\hline$K_{w}$ & correction factor for pier width or pile diameter \\
\hline$K_{y W}$ & depth size \\
\hline$K_{I}$ & flow intensity \\
\hline$K_{D}$ & sediment size \\
\hline$K_{G}$ & channel geometry \\
\hline$S_{0}$ & scour depth at $\mathrm{C} / \mathrm{H}=0.5, \mathrm{R} / \mathrm{D}=5.63$ \\
\hline$S_{\max }$ & maximum scour depth against different rotor radius at $\mathrm{C} / \mathrm{H}=0.5$ \\
\hline$S_{\min }$ & minimum scour depth against different rotor radius at $\mathrm{C} / \mathrm{H}=0.5$ \\
\hline$u$ & coefficient \\
\hline$\sigma$ & coefficient \\
\hline
\end{tabular}




$\begin{array}{ll}a_{0-3} & \text { coefficients } \\ b_{0-2} & \text { coefficients } \\ c_{0-2} & \text { coefficients } \\ \hat{x} & \text { dimensionless horizontal distance from centre of foundation } \\ \hat{y} & \text { dimensionless vertical distance from initial flat surface }\end{array}$

\section{Reference}

[1] García-Olivares A, Solé J, Osychenko O. Transportation in a 100\% renewable energy system[J]. Energy Conversion \& Management, 2018, 158:266-285.

[2] World Energy Outlook Special Report 2016. Energy and Air Pollution; 2016.

[3] Khan J, Bhuyan G S. Ocean Energy: Global Technology Development Status[J]. Ocean Energy Systems Oes, 2011.

[4] Paraschivoiu I. Wind turbine design with emphasis on Darrieus concept[J]. 2002.

[5] Dey S. Local scour at piers, part 1: A review of development of research[J]. International Journal of Sediment Research, 1997, 12(2):23-44.

[6] Neill CR. Guide to bride hydraulics. Toronto, Canada: Roads and Transportation Association of Canada, University of Toronto Press; 1973.

[7] Breusers H N C, Nicollet G, Shen H W. Local Scour Around Cylindrical Piers[J]. Journal of Hydraulic Research, 1977, 15(3): 211-252.

[8] Richardson EV, Davis SR. Evaluating scour at bridges. 4th ed. Washington, DC: Hydraulic engineering circular no. 18 (HEC-18), Federal Highway Administration, 2001.

[9] Sumer BM, Fredsøe J. Scour around a pile in combined waves and currents. Journal of Hydraulic Engineering, 127. ASCE: 403-11.

[10] Simons R, Weller J, Whitehouse R. Scour Development around Truncated Cylindrical Structures[M] Coastal Structures 2007:(In 2 Volumes). 2009:1881-1890.

[11] Harris J M, Whitehouse R J S, Benson T. The time evolution of scour around offshore structures[J]. Maritime Engineering, 2010, 163(1):3-17.

[12] Sun X. Numerical and Experimental Investigation of Tidal Current Energy Extraction [J]. Transilvania University Publishing House Brasov, 2008, 20(2):135-148. 
[13] Harrison M E, Batten W M J, Myers L E, et al. A comparison between CFD simulations and experiments for predicting the far wake of horizontal axis tidal turbines[C] IET, 2009:613 - 627.

[14] Lam W H, Chen L. Equations used to predict the velocity distribution within a wake from a horizontal-axis tidal-current turbine[J]. Ocean Engineering, 2014, $79(3): 35-42$.

[15] Tahani M, Babayan N, Astaraei F R, et al. Multi objective optimization of horizontal axis tidal current turbines, using Meta heuristics algorithms[J]. Energy Conversion \& Management, 2015, 103:487-498.

[16] Chen L, Lam W H. Slipstream between marine current turbine and seabed[J]. Energy, 2014, 68(8):801-810.

[17] Ghasemian M, Ashrafi Z N, Sedaghat A. A review on computational fluid dynamic simulation techniques for Darrieus vertical axis wind turbines[J]. Energy Conversion \& Management, 2017, 149(1):87-100.

[18] Wang L B, Zhang L, Zeng N D. A potential flow 2-D vortex panel model: Applications to vertical axis straight blade tidal turbine[J]. Energy Conversion \& Management, 2007, 48(2):454-461.

[19] Lam W H, Dai Y M. Numerical study of straight-bladed Darrieus-type tidal turbine[J]. The Institution of Civil Engineer - Energy, 2009, 162(2):67-76.

[20] Strickland J. H. The Darrieus Turbine: A Performance Prediction Model Using Multiple Streamtubes. Sandia National Laboratories, Albuquerque, 1975, Report SAN75- 0431.

[21] Chen L, Lam W H. Methods for predicting seabed scour around marine current turbine[J]. Renewable \& Sustainable Energy Reviews, 2014, 29(7):683-692.

[22] Hill C, Musa M, Chamorro L P, et al. Local Scour around a Model Hydrokinetic Turbine in an Erodible Channel[J]. Journal of Hydraulic Engineering, 2014, 140(8):04014037.

[23] Zhang J, Gao P, Zheng J, et al. Current-Induced seabed scour around a pilesupported horizontal-axis tidal stream turbine[J]. Journal of Marine Science \& Technology, 2015, 23(6):929-936.

[24] Giles J, Myers L, Bahaj A, et al. Foundation-based flow acceleration structures for marine current energy converters[J]. Iet Renewable Power Generation, 2011, 5(4):287298. 
[25] Rajaratnam N. Erosion by Plane Turbulent Jets[J]. Journal of Hydraulic Research, 1981, 19(4):339-358.

[26] Hamill G A, Mcgarvey J A. The Influence of a Ship's Rudder On the Scouring Action of a Propeller Wash[J]. Journal of Agronomy \& Crop Science, 1997, 193(4):247-261.

[27] Hong J H, Chiew Y M, Cheng N S. Scour Caused by a Propeller Jet[J]. Journal of Hydraulic Engineering, 2013, 139(9):1003-1012.

[28] Melville B W. Pier and Abutment Scour: Integrated Approach[J]. Journal of Hydraulic Engineering, 1997, 124(2):125-136.

[29] Zhao M, Cheng L, Zang Z. Experimental and numerical investigation of local scour around a submerged vertical circular cylinder in steady currents[J]. Coastal Engineering, 2010, 57(8):709-721. 